\title{
Capítulo 1 - 0 harém nas narrativas de viagem ao Levante nos fins do século XVI e no século XVII
}

\author{
Marina de Oliveira Soares
}

\section{SciELO Books / SciELO Livros / SciELO Libros}

SOARES, M. O. O harém nas narrativas de viagem ao Levante nos fins do século XVI e no século XVII. In: $O$ harém ao rés do chão: imaginário europeu e representações médicas sobre o lugar-segredo, 1599-1791 [online]. São Bernardo do Campo, SP: Editora UFABC, 2017, pp. 21-108. ISBN 978-8568576-81-6. https://doi.org/10.7476/9788568576816.0003.

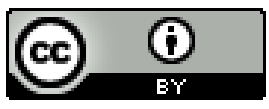

All the contents of this work, except where otherwise noted, is licensed under a Creative Commons Attribution 4.0 International license.

Todo o conteúdo deste trabalho, exceto quando houver ressalva, é publicado sob a licença Creative Commons Atribição 4.0.

Todo el contenido de esta obra, excepto donde se indique lo contrario, está bajo licencia de la licencia Creative Commons Reconocimento 4.0. 


\title{
O harém nas narratívas de víagem ao Levante nos fíns do século XVl e no século XVII
}

\author{
"Of all the pleasures in the world, \\ travell is (in my opinion) the \\ sweetest and most delightful". \\ Thomas Coryat (c. 1577-1617), \\ escritor e viajante inglês, 1776, p. xvii
}

Neste capítulo, duas questões serão tratadas. A primeira se refere à forma como os europeus enxergavam e representavam o Levante na sua produção textual ao longo do século XVII; e a segunda, foco principal deste livro, investiga como o harém era conceituado e descrito dentro dessa produção durante os fins do século XVI e ao longo do século XVII. Para tanto, será preciso examinar os possíveis conceitos de Oriente ${ }^{7}$ ou Levant em um dado número de

\footnotetext{
${ }^{7}$ Uso o termo em itálico para indicar a construção históricosocial do termo Oriente, como discute Edward Said (1990) na obra Orientalismo: O Oriente como invenção do Ocidente.
} 
dicionários europeus e, depois disso, situar as características atribuídas ao harém islâmico. Nesse último caso, usarei tanto os dicionários europeus quanto um conjunto de oito narrativas de viagem publicadas originalmente em inglês e em francês.

De início, é preciso ressaltar que considero aqui o começo da modernidade como ponto de viragem nas concepções europeias sobre os muçulmanos. Por razões que pretendo explorar ao longo deste livro, esse período marca uma significativa mudança no comportamento e no discurso em relação às terras islâmicas quando comparados ao período medieval. Além disso, a investigação sobre as origens e a formação de um suposto imaginário sobre o harém - tendo-se como fontes as narrativas de viagem permitirá uma análise comparativa com a fonte principal deste trabalho cujo tema se centra no olhar europeu sobre os haréns no Reino de Marrocos, no século XVIII.

A discussão sobre o primeiro problema - a delimitação do conceito de Oriente ou Levante - se faz necessária para que possamos situar as relações que se estabeleciam entre os europeus e os povos da Ásia, em particular aqueles que professavam a religião islâmica. O Levante, no século XVII, remetia quase sempre ao Império Otomano e, de maneira menos destacada, à Pérsia. Quando lemos informações sobre o Norte da África, era o nome do Reino ou de alguma cidade que os autores apontavam. Isso por si só já questiona a noção de uma região islâmica homogênea. Ao lado disso, é preciso lembrar que o termo Oriente não é encontrado de forma disseminada nos viajantes da primeira metade do século XVII, como veremos adiante. 
A análise da conceituação do termo Oriente e também do Levante nos ajudará a indicar a maneira - singular ou plural - pela qual os europeus entendiam e representavam as sociedades islâmicas. Isso, entretanto, traduzia apenas um elemento dentre tantos outros que compunham as relações entre os europeus e os árabes, turcos e persas. Portanto, será necessário verificar também de que modo os europeus empregavam as suas representações sobre esses povos no sentido de construir identidades nacionais ou mesmo uma identidade europeia. Esse tema será apresentado no item "O 'outro' na construção da identidade europeia”, no Capítulo 2.

Após o levantamento de tais definições, passaremos aos apontamentos sobre o harém. Aqui, as fontes principais empregadas para se investigar o tratamento dado ao harém islâmico será um grupo de narrativas de viagem produzidas durante o fim do século XVI e o correr do século XVII - matéria deste capítulo -, somado àquelas construídas ao longo do século XVIII, tema a ser tratado no Capítulo 2. Pela imensa extensão de fontes, uma série de opções foi feita, obedecendo-se ao critério de seleção instituído aqui. Tais critérios serão apontados à medida que os textos forem analisados.

\subsection{O Oriente e o harém nos dícionáríos europeus}

Quando examinamos os dicionários europeus produzidos ao longo do século XVII e as narrativas de viagem do mesmo período, constata-se sem muita demora um fator recorrente: a heterogeneidade circundava o 
conceito da palavra Oriente. No caso das três grandes regiões tratadas aqui - Império Otomano, Império Persa e Norte da África -, há que se considerar ainda outra variável: a posição particular do Norte da África em relação aos outros dois impérios. Por fim, o próprio "Norte da África" não deve ser tomado como uma área homogênea, como ficará evidenciado quando tratarmos o caso específico do Marrocos.

A maior parte dos viajantes do século XVII optava por escrever Levante ou o nome mesmo da cidade por eles visitada. Uma possível fluidez em torno do conceito de Oriente pode ser exemplificada nas definições dadas pelos dicionários franceses e ingleses. Na edição de 1690 do dicionário de Antoine Furetière (1619-1688), havia quatro entradas para "Oriente" e outras quatro entradas para "oriental”. Desse modo, a primeira definição atribuída a Oriente era geográfica, ou seja, o lugar onde se elevam o "Sol e os astros" (FURETIÈRE, 1690, p. 810). A explicação geográfica era completada em uma das entradas para "oriental", isto é, tratava-se do lugar situado a Oriente da Europa. Portanto, a Síria e a Palestina eram países orientais, sendo o Japão oriental em relação à China (p. 810). As definições se referiam, além disso, às línguas como "o Hebreu, o Caldeu, o Siríaco e o Árabe”, ou mesmo à jovialidade [jeunes personnes]. Já o termo "Levante" - embora exibisse definições muito próximas das encontradas para "Oriente" - possuía uma indicação diretamente vinculada aos "Maometanos" [Mahometans].

Quatro anos depois, o Dicionário da Academia Francesa [Dictionnaire de l'Académie Françoise] também considerava "Oriente" e "Levante" como sinônimos, mas ali se 
fazia notar que o "Oriente é tomado pelas províncias da grande Ásia, como o Império Mogol e o reino de Sião e da China" (1694, vol. 2, p. 159). Nesse dicionário, embora o Levante fosse associado à "Pérsia, à Ásia Menor e à Síria", não havia qualquer conexão imediata entre essa palavra e os árabes ou os muçulmanos, normalmente chamados de maometanos pelos europeus desta época (1694, vol. 1, p. 641).

O primeiro dicionário inglês de que se tem notícia, A table alphabetical, de Robert Cawdrey (1604), listava apenas 2.543 palavras. As definições sobre elas eram concisas e o vocábulo "Oriente", tanto quanto "Leste" ou "Levante", não constavam do trabalho de Cawdrey". Foi preciso esperar pelo século XVIII para encontrar o termo em um dicionário inglês. O Lingua Britannica Reformata, de Benjamin Martin (1749), definia Oriente por Leste [East], ou aquele que pertence ao Leste $(1749$, p. 443). Até o dicionário de maior destaque da sociedade inglesa não era muito esclarecedor quanto à definição do termo. O dicionário do Dr. Samuel Johnson (1709-1784), de 1755, possuía duas entradas para "Oriente" e duas para "Oriental”. Nos dois casos, havia tanto referência ao nascer do sol, ou luz solar, quanto a leste, habitante dessa parte do mundo [East] (1768, p. 614).

As definições sobre Oriente nas sequentes edições do Dicionário da Academia Francesa não trariam quaisquer mudanças. As publicações de 1718, 1740, 1762 e 1798

8 CAWDREY, R. A Table Alphabeticall of hard usual english words. Edited by Robert A. Peters. Gainesville: Scholars' Facsimiles \& Reprints, [1604] 1966, <http://www.library.utoronto.ca/utel/ret/cawdrey/cawdrey0.html> 
apresentavam o mesmo significado para esse termo. Outra semelhança entre as cinco edições desse dicionário - de 1694 a 1798 - era a equivalência atribuída entre as palavras Oriente e Levante. Mas ainda que os vocábulos fossem colocados como sinônimos, nem por isso se deixava de notar, a partir da edição de 1740, a diferença entre o "comércio do Oriente", feito na "Ásia Oriental pelo Oceano", e o "comércio do Levante", feito na "Ásia ocidental pelo Mediterrâneo". Como sublinha Mouna Alsaid, "o termo Oriente é um conceito político, e como tal, varia de acordo com as concepções geopolíticas" que estavam neste momento em transformação (2009, p. 11).

Além dos conceitos de Oriente e de Levante, os dicionários deste período nos trazem informações importantes sobre as regiões específicas estudadas aqui. Enquanto o dicionário inglês Lingua Britannica Reformata apontava o termo "Persas" [Persians], indicando que se tratava de "habitantes ou nativos da Pérsia" (MARTIN, 1749, p. 810), o Dicionário da Academia Francesa traria a entrada para "Pérsia” [Perse] somente em 1762 (vol. 2, p. 353). A definição dessa palavra, contudo, não exibia a menor relação com a geografia ou com os habitantes da Pérsia. Ali, o que se lia era sobre "a bela tela pintada" que vinha desse lugar. O Marrocos, por sua vez, não era lembrado nesses dicionários. Nem mesmo o termo "Barbárie" - usado para se referir de forma ampla ao Norte da África - era colocado como seu sinônimo?.

9 O termo Bárbarie não se referia a "toda a área norte do Saara”, agora chamada Norte da África ou Magrebe, mas apenas à sua parte norte, que "compreende a planície costeira e as montanhas ou, em outras palavras, os portos e seu interior" (THOMSON, 1987, p. 11). 
Nos relatos de viagem, o emprego da palavra "Barbárie” para se referir ao Norte da África era disseminado. É certo que o termo poderia ser utilizado com a intenção de se aludir aos berberes, povo estabelecido nas montanhas do Atlas, entretanto, havia nele também uma carga valorativa. O uso do vocábulo "Barbárie" com a intenção de ultrajar os muçulmanos do Norte da África é defendido por Nabil Matar, para quem a crescente hostilidade em relação aos islâmicos levou à aplicação desse termo (MATAR, 1999 apud RAMLI, 2009, p. 46). O juízo de valor embutido na palavra pode ser verificado tanto em uma apreciação interna ao Marrocos quanto na comparação com os seus vizinhos geográficos.

O texto do médico e viajante William Lempriere é bastante esclarecedor em relação ao tom depreciativo acerca do Marrocos. A sua narrativa ressaltava com vigor as deficiências, as degenerações e os problemas encontrados nesse Reino. Do solo às construções arquitetônicas, englobando o excesso de santuários e a ignorância médica dos doentes, tem-se a sensação de que quase tudo beirava a esterilidade e o descuido. Quando o médico constatava a presença de terras férteis, dizia ele que isso demonstrava como a natureza tinha a intenção de fazer residir nesse lugar "um povo mais civilizado" do que os seus habitantes (1800, p. 56).

Também em comparação com outras regiões árabes ou islâmicas, o Norte da África ocupava uma posição inferior. O exame das narrativas de viagem nos mostra como os destinos mais procurados pelos europeus consistiam em regiões do Império Otomano - com destaque para Istambul - e da Pérsia. Quando o Norte da África 
compunha o intento do viajante, era o Egito certamente o local mais visitado e não a "Barbárie". Não será difícil encontrar afirmações como a de Lempriere que destacava a produção de tapetes do Marrocos, mas afirmava logo em seguida que esses eram um pouco inferiores àqueles feitos na "Turquia" (p. 70).

Já a entonação valorativa e generalizante do termo pode ser encontrada na opinião de outro viajante, o padre francês Joseph Besson (1610-1691), em sua passagem pela Síria em 1660. Ao apontar as características negativas dessa sociedade - como aquela que se referia ao fato de tais pessoas não terem fé, o que as aproximaria dos "animais" -, ele afirmava que "estes povos do Levante" guardavam "muita proximidade com os Bárbaros" (1660 apud HARRIGAN, 2008, p. 81). Os "bárbaros" em questão eram os povos da América, pois o padre lamentava ainda a semelhança entre os "Sírios árabes" e os "Selvagens" do Canadá.

Diante desse breve panorama, é adequado pensar tanto na heterogeneidade do termo Oriente ou Levante quanto na existência de três grandes regiões islâmicas nos textos do período moderno europeu a serem analisadas aqui: o Império Otomano, a Pérsia e a "Barbárie". Mesmo dentro desses blocos, havia particularidades notáveis. O Egito era tomado pelos europeus como uma importante região dentro dos domínios do Império Otomano. Do mesmo modo, deve-se ressaltar que a regência otomana exercida sobre Argel [na Argélia], Túnis [na Tunísia] e Trípoli [na Líbia] era monopolizada por apenas um homem, o dey, mas a lealdade aos otomanos se revelou gradualmente corroída (OGOT, 1992, p. 256). Por fim, 
fronteiras políticas e identidades nacionais na Europa não se resumiam a fator consolidado, o que dificultava também a manutenção de uma visão linear e imóvel sobre os povos islâmicos.

Um percurso pelas definições sobre as habitações femininas nos palácios islâmicos também nos revela os variados entendimentos a que esse espaço estava submetido. Antes disso, deve-se notar que foi apenas no século XVII que os dicionários ingleses passaram a ser publicados. Até então, havia dicionários bilíngues, como inglês/ francês ou inglês/latim (BARBER; BEAL; SHAW, 2009, p. 216). Considerando-se apenas as publicações deste século, verifica-se a ampla ausência da palavra "harém" nos dicionários ingleses e franceses. No caso do dicionário de Robert Cawdrey, de 1604, nem a palavra harém, nem a palavra serralho eram listadas.

No final do século XVII, o lexicógrafo Elisha Coles (c. 1640-1680), no seu dicionário bilíngue inglês/latim, apresentava o termo "serralho" apenas como Aula Imperatoris Turcici, ou seja, palácio dos imperadores turcos (1679, [s. p.]). Significado similar era adotado por Thomas Blount (1618-1679), na edição de 1707 da Glossographia Anglicana Nova - dicionário publicado originalmente em 1656. Ali, o serralho era entendido simplesmente como o "Palácio do Grão-Senhor" (1707, [s. p.]).

Para provar as oscilações com que o termo serralho aparecia e a partir das quais era conceituado nos dicionários ingleses, deve-se lembrar da obra de Edward Phillips (1630-c. 1696). O dicionário, intitulado O Novo Mundo das Palavras Inglesas [The New World of English Words] e publicado originalmente em 1658 (DRAKE, 2003, 
p. 853), trazia em sua edição "revista, corrigida e ampliada" de 1706 um significado bem mais extenso do que aquele lido em Thomas Blount. O serralho era assim definido: "um palácio dos príncipes entre as nações do Leste, especialmente, aquele do imperador dos Turcos, onde as suas concubinas são mantidas como séquito ou comitiva de mulheres" (PHILLIPS, 1706, [s. p.]).

A instabilidade do termo "serralho" será encontrada também nos dicionários franceses. No dicionário de Antoine Furetière, de 1690, não havia entrada para harém, mas somente para serralho [Serrail]. Ali, as definições sobre a palavra eram abundantes. A primeira delas apresentava o serralho como o "palácio de um príncipe, de um grande senhor no Oriente". Ainda nessa definição, o autor informava que o palácio onde residia o "Grão-Senhor em Constantinopla" também abrigava as suas concubinas. $\mathrm{Na}$ sequência, o serralho era tomado como um lugar de "deboche", uma casa em que "alguns grandes senhores apoderam-se de mulheres para se divertirem". Por fim, serralho era apontado como um celeiro das casas reais onde se mantinham "leões, ursos ou outros animais selvagens" (FURETIÈRE, 1690, vol. 3, p. 532).

No Dicionário da Academia Francesa, de 1694, também não havia entrada para o termo harém. A indicação que fazia referência aos palácios islâmicos era a palavra serralho [Serrail], definida como "palácio" onde ficavam os príncipes (1694, vol. 2, p. 471). Ali, e ao contrário do que alegava Furetière (1690), alertava-se sobre o caráter inadequado em se tomar o serralho como um local de manutenção de mulheres com vistas ao prazer. Essa conceituação era distinta daquela que se lia no dicionário 
organizado por Pierre Richelet ainda em 1694. Nesse caso, o autor afirmava não apenas que o serralho era o local em "Constantinopla onde o Grão-Senhor tem as suas mulheres", como sustentava serem essas mulheres "muito belas" (1694, p. 367).

A partir das indicações expostas nos dicionários, dois fatores deverão ser considerados em torno da palavra "harém". A primeira diz respeito à lacuna que se observa em relação ao emprego desse termo durante a extensão do século XVII. A ausência dessa palavra não era exclusividade dos dicionários, como se poderá notar nas narrativas de viagem analisadas neste capítulo. Além disso, o conceito constantemente atribuído à palavra serralho atravessaria os Seiscentos. Se havia alguma unanimidade acerca do serralho islâmico nas tintas dos autores europeus era a sua definição física, ou seja, o entendimento do serralho como um palácio.

\subsection{As várías faces do "outro"}

Os primeiros contatos sistemáticos entre os povos latinos e o "outro" - asiático - se deram nas "Cruzadas", a partir do século XI. Mas ainda que a motivação dessas expedições tenha sido o combate aos "infiéis", a relação que se estabeleceu entre os cristãos e os muçulmanos não deve ser resumida ao confronto, por todo o tempo (PERNOUD, 1960, p. 197). Por isso, é possível que se proponha a tese, como a de Edouard Perroy, que afirma serem as “'Cruzadas' uma 'instituição permanente', através da qual se instaurou um vai e vem regular entre a 
Europa e a Ásia” (1995, p. 269). Nesse contato, verifica-se seguramente a face combativa entre os lados, mas também uma proximidade entre os grupos cristão e islâmico. Diante disso, tal e qual as canções de gesta, o Levante era apresentado como "um monstro de crueldade, de barbárie, de violência de guerra", para, em seguida, revelar-se "um encantador de mil feitiços, de luxo e de opulência" (MAGRI, 1995, p. 13). Entre esses dois polos antitéticos, haveria ainda inúmeras nuances de representação.

Durante o período medieval, já se podia vislumbrar, portanto, uma marcação das diferenças entre o que era característico da Europa cristã, cujos limites geográficos, grosso modo, contornam a Europa ocidental, e um grupo que lhe era estranho, ameaçador por vezes, e que se destacava por seus elementos religiosos: os muçulmanos. Entretanto, é necessário considerar que, se havia um desconforto da cristandade europeia em relação a esse "outro", houve, do mesmo modo, momentos de "encontros culturais", nos quais, muitas vezes, a aproximação com os valores árabes ou islâmicos e até a admiração por tal sociedade não eram incomuns. $\mathrm{O}$ fato é que durante esse período não havia uma ideia de Europa bem delimitada, sequer de uma cristandade que fosse homogênea de leste a oeste do Império Romano. Em virtude da complexidade que atravessava essa sociedade - depois identificada sob a alcunha de Ocidente -, é possível encontrar, por exemplo, uma maior afinidade entre cristãos de Bizâncio, da Ásia Menor e da Síria com o "mundo muçulmano do que com os seus correligionários do Ocidente" (HENTSCH, 1988, p. 59), ou, ainda, ler em um cronista cristão elogios a seus 
inimigos durante as "Cruzadas" ${ }^{10}$. Não é demais lembrar que os próprios "cruzados" atacaram Constantinopla em 1203 (MADDEN, 2004, p. 104-109).

Ocorre, contudo, que nem todos os cristãos que se punham a escrever sobre o Islã mantinham algum tipo de relação direta com os muçulmanos. $\mathrm{E}$ isso não impediu, por certo, que houvesse uma expansão dos escritos sobre os “infiéis". Dentro dessa produção, não havia uma postura uniforme sobre o Islã, como se poderá notar nas representações produzidas entre a chamada "Baixa Idade Média" e a modernidade ${ }^{11}$. $\mathrm{O}$ interesse pelas características socioculturais dos muçulmanos - que podemos encontrar nos relatos de viagem - é um exemplo disso, já que o cenário de combate perderia espaço para a própria importância da experiência de viagem. A "heresia maometana”, entretanto, será ao longo desse período combatida "com maior ou menor grau de virulência” (BERRIOT, 1986, p. 11-25).

Pela quantidade de lendas, escritos vexatórios e biografias dedicadas ao mensageiro islâmico, Muhammad ${ }^{12}$ (c. 570-632), há razões para considerar que no período medieval o elemento que mais incomodava os cristãos era a expressão religiosa do Islã, de modo que os ataques ao "outro" não impediriam a disseminação dos escritos

\footnotetext{
10 Trata-se de um cronista anônimo da primeira "Cruzada" que destacou a "sagacidade, os dons guerreiros e a bravura dos turcos" (HENTSCH, 1988, p. 59).

${ }^{11}$ Autores como Paul Bancourt defendem mudanças nas representações europeias sobre os muçulmanos ao longo da própria "Idade Média". Ele argumenta que "pelo último quarto do século XII, o retrato do sarraceno leal cresceu em popularidade" (FRASSETTO; BLANKS, 1999, p. 59).

12 Ver o capítulo "Maomé" em Estrutura do Harém: Despotismo Asiático no Ocidente Clássico (GROSRICHARD, 1988, p. 132-160).
} 
filosóficos e médicos árabes entre as elites cristãs. Thierry Hentsch iria mais longe, ao afirmar que é a partir do saber árabe que as "novas elites europeias se constituem como elites científicas. É deste saber que elas tiram uma parte importante de sua autoridade" (HENTSCH, 1988, p. 67).

Os ataques ao mensageiro do Islã continuaram ao longo da "Idade Média", ao mesmo tempo que o crescimento do Império Otomano levaria a mudanças no discurso e no comportamento dos cristãos em relação aos muçulmanos. O século XVII é emblemático nesse sentido, pois se passava a uma produção intelectual cada vez mais vasta sobre o Levante. Sobre isso, Alain Grosrichard ressalta que a primeira publicação sobre os turcos voltada a um entendimento do grande público é História geral da religião dos turcos, de Michel Baudier, de 1626 (1988, p. 136), autor que compõe o conjunto de relatos a serem examinados neste capítulo.

É possível encontrar dentre os viajantes-autores um uso corrente do termo maometano para se referir à religião islâmica. Mais ainda: verifica-se o emprego do termo turco para designar os muçulmanos de forma ampla. Para citar um exemplo, podemos lembrar o processo do Santo Ofício contra o moleiro Menocchio, de Friuli [nordeste da Itália], na segunda metade do século XVI, analisado pelo historiador italiano Carlo Ginzburg. Ao falar sobre as religiões conhecidas, o moleiro fazia menção aos "cristãos, heréticos, turcos, judeus" (2006, p. 52), o que pode nos indicar que a palavra turco era usada como sinônimo de muçulmano $^{13}$. A apropriação desse designativo remetia,

13 O historiador Felix Konrad, em From the 'Turkish Menace' to Exoticism and Orientalism: Islam as Antithesis of Europe (1453-1914)?”, afirma que, 
certamente, à forte proximidade turca frente à Europa. $\mathrm{O}$ termo muçulmano, de outro modo, que alude à religião islâmica, conhecida dos europeus desde o século VIII d.C. com a presença de árabes-islâmicos na península Ibérica ${ }^{14}$, não era empregado de forma disseminada pelos viajantes.

Como anunciavam os viajantes franceses Jean-Baptiste Tavernier (1605-1689) - em sua viagem pelo Império Otomano, pela Pérsia e pelas Índias Orientais, entre 1630 e 1668 - e Jean de Thévenot (1633-1667) - que empreendeu duas viagens ao Levante -, não era necessário descrever em pormenores a religião islâmica, afinal, muitos já haviam escrito a seu respeito (HARRIGAN, 2008, p. 138). As viagens para a Ásia e para a África, contudo, multiplicavam-se. A curiosidade, atrelada a uma gama variada de projetos pessoais, atraía viajantes para regióes islâmicas e gerava uma produção crescente de relatos de viagem. O tema religioso perdia espaço e dava lugar às observações sobre a vida cotidiana nessas sociedades. Nesse cenário, o interior dos palácios reais emergia como um dos objetos de interesse dos viajantes-escritores.

\subsection{As víagens ao Levante}

No século XVII, um extenso número de mercadores, diplomatas, religiosos ou curiosos rumou em direção a regiões islâmicas com intentos os mais variados como

desde a metade do século XV, "tornou-se costume equiparar muçulmanos com turcos” (2011, [s. p.]).

14 Sobre a expansão do Império Árabe-islâmico na península Ibérica em 711, ver "O califado de Damasco" (HOURANI, 2006, p. 48-57). 
se pode perceber em seus registros de viagem. Como o Império Otomano era um dos lugares mais visitados - particularmente a sua capital, Istambul -, podemos supor que muitos homens e algumas mulheres tenham sido estimulados a viajar por acreditarem no enfraquecimento do poder otomano e no seu sistemático declínio ${ }^{15}$. Há que se assinalar, contudo, que a própria força político-militar otomana se revelava um atrativo para os europeus interessados em tecer negócios com esse império.

Some-se a isso um ranço religioso causado pelos turcos nas populações cristãs europeias, ainda durante o século XVII. O viajante francês Du Loir, que permaneceu dezessete meses em Istambul, temia que a "tirania da dominação" turca pudesse subjugar toda a cristandade, como ocorrera aos gregos $(1654$, p. 18). Outro viajante francês em passagem pelo Império Otomano, Jean Coppin (c. 1615-c. 1690), afirmava que o poder otomano era uma "torrente que nos ameaça incessantemente, que penetrou profundamente e se prepara para inundar toda a Europa, como já inundou a parte mais bela da Ásia" (1686, p. 7). Por isso, uma nova "Cruzada" não apenas se justificava, como tardara demais para ser empreendida (GROSRICHARD, 1988, p. 30).

Havia, por fim, o próprio discurso do despotismo povoando as mentes europeias, fator que movia os europeus ao Império Otomano com a intenção de perscrutá-lo

15 Para Alain Grosrichard, se durante os séculos XV e XVI o Império Otomano era tido como "um inimigo temido, até mesmo odiado, mas respeitado", a partir do século XVII os viajantes europeus descobriam a sua esclerose (1988, p. 29). 
para poder evitá-lo ${ }^{16}$. Nenhuma dessas razões, contudo, era mais sólida do que as oportunidades de negócio que a viagem poderia oferecer. A atração pelo Levante neste momento era fortemente marcada pelas predisposições comerciais. Do Mar Mediterrâneo à região do Oceano Índico, havia uma crescente presença de mercadores europeus. Como afirma Albert Hourani, Alepo se transformou no principal centro de comércio do Próximo Oriente, incluindo-se aí uma grande comunidade de comerciantes ingleses (1989, p. 229). O comércio em Alepo já no século XVI era tão conhecido, que autores como um certo Richard Wragg diria que se furtaria de falar sobre esse assunto, devido ao grande conhecimento a seu respeito (MACLEAN, 2004, p. 84).

O médico inglês William Lempriere também reconhecia a potencialidade do comércio entre a Europa e o Reino de Marrocos, mas alertava que o único impedimento material a tal atividade era a "inconveniência e insegurança dos portos" no reino mouro (1800, p. 65). Esse incitamento das relações mercantis levou a mudanças de ordem política em prol dos europeus; afinal, os países da Europa passaram a contar com embaixadores e cônsules nos domínios otomanos, ao passo que estes somente teriam embaixadas próprias no período das guerras napoleônicas, no século XIX (HOURANI, 1989, p. 229-230). Foi apenas em 1850 que os persas fixaram missões diplomáticas permanentes em Londres, São Petersburgo e em Istambul (DARYAEE, 2012, p. 330). Situação idêntica

\footnotetext{
16 O uso do despotismo para pensar o crescimento do poder político absoluto na Europa é amplamente desenvolvido por Alain Grosrichard (1988, p. 9-72), em particular na "Genealogia do Monstro".
} 
ocorria com o Marrocos, cujo único consulado permanente antes de sua independência para a França, em 1956, era aquele estabelecido na colônia britânica de Gibraltar (BROWN, 2012, p. 1).

As viagens deste período inauguraram uma literatura particular que não se fazia conhecida somente de um pequeno número de letrados. A linguagem dos viajantes-autores, menos afeita a uma severidade de gabinete, contribuía certamente para uma disseminação de suas obras, já que estava fincada no avanço da impressão textual. As viagens ganhavam espaço, e com elas crescia a produção dos registros impressos, o que promoveu a formação e a consolidação deste mercado literário (REQUEMORA, 2002, p. 249).

Afora o uso de uma linguagem mais simples, este tipo de literatura - que ia se constituindo em um gênero - guardava duas diferenças sobressalentes em relação a outros escritos. A documentação sempre teve uma "função importante na viagem" (SHERMAN apud HULME; YOUNGS, 2002, p. 17). Deve-se lembrar, aqui, que o resultado de uma viagem excedia muitas vezes o texto. Foram numerosos os viajantes que usaram mapas, gravuras de animais, de pessoas, outros anexos, para ampliar o conhecimento descrito na narrativa. Ao longo do século XVIII, os viajantes passaram a recolher inclusive objetos particulares à sociedade visitada. Como exemplo, pode-se citar o caso de James Cook que em três viagens pelo Pacífico, entre 1768 e 1780 , coletou centenas de objetos nas sociedades visitadas ${ }^{17}$. Some-se a isso o caráter testemunhal

17 O Museu Nacional da Austrália, em parceira com a Universidade de Göttingen, disponibiliza o acervo online: <http://www.nma.gov.au/ history/cooks_pacific_encounters $>$. 
do texto, daí a confiança atribuída ao relato mesmo. A discussão sobre a estrutura da narrativa será retomada no Capítulo 3.

Narrativas de viagem já eram produzidas com frequência antes do século XVII, especialmente em virtude das viagens europeias ao "Novo Mundo". A novidade dos relatos dos Seiscentos será, então, o largo tratamento dado ao tema do Levante. Já se poderá perceber em tais narrativas uma consolidação de determinadas ideias sobre os muçulmanos, que se tornariam, pouco a pouco, generalizadas. Por exemplo, já se lia no texto de um capelão inglês a afirmação de que, se conhecessem a miséria do povo que vivia sob a tirania dos otomanos, os ingleses poderiam se considerar a mais feliz das nações (BAKTIR, 2007, p. 11). Não sem motivo, o despotismo era um grande tema de reflexão dos autores europeus durante o século XVIII, como já ressaltado.

Os registros de viagem buscavam realçar as diferenças entre a Europa e o Oriente para além do sentido religioso. Eram as características sociais das regiões islâmicas que ganhavam destaque nesse tipo de literatura. Mas são justamente esses elementos que nos permitem verificar de que maneira se operava a aproximação entre um europeu e um árabe, persa ou turco. Então, nesse mosaico de relações, será possível encontrar autores que se "contentam" em "falar de maneira geral, porque são todos os mesmos povos” (PYRARD, 1619 apud HARRIGAN, 2008, p. 87); outros que poderiam nutrir admiração pelo conhecimento de povos distantes; e outros, ainda, que poderiam encontrar no Levante ruínas de um passado glorioso. Não é menos certo que essas concepções pudessem aparecer de forma combinada em um mesmo autor. 
A elaboração da narrativa de viagem não nascia, por suposto, de uma experiência isolada de seu autor, ou seja, o viajante partilhava já de uma tradição narrativa e oral anterior ao seu próprio tempo (HARRIGAN, 2008, p. 47). Nesses contatos entre o viajante e a sociedade visitada, não é improvável, portanto, que o primeiro construísse o seu relato pautando-se em alguma medida nesse conjunto prévio de ideias. É necessário lembrar, contudo, dos limites de verificação de tais apropriações. Não há como dimensionar precisamente o alcance e as sucessivas transformações - se é que assim ocorreu - de representações medievais, por exemplo, nos textos de viagem modernos, uma vez que aquelas estavam calcadas em uma tradição eminentemente oral. Ainda que seja assim, buscarei indicar os possíveis vestígios da cultura oral nos relatos de viagem, no Capítulo 3.

Dados os meandros de tais "encontros culturais", é razoável que consideremos as particularidades de determinadas viagens, para que em seguida se possa esboçar um quadro mais amplo das relações tecidas. Muitas foram as imagens negativas criadas sobre os árabes ou muçulmanos. Porém, em igual medida, muitas tentativas de aproximação e de compreensão das culturas estrangeiras podem ser apreendidas dos viajantes, o que nos permite aventar a história dialógica construída por essas sociedades em torno do Mediterrâneo. Os frequentes contatos entre esses povos nos ajudarão a apontar, por fim, as razões de determinadas imagens terem se sobrepujado a outras, a ponto de se afigurarem em um cânone relativamente delimitado sobre o muçulmano. 
Encarando os relatos de viagem enquanto fontes factuais (HARRIGAN, 2008, p. 37), o que se pretende aqui é verificar de que modo se estabelecia o contato entre o viajante e o povo visitado, atentando-se a qualquer substrato de valores europeus na formação das imagens sobre uma sociedade que não lhe era familiar. Consciente das funções políticas, econômicas ou mesmo religiosas que as sociedades islâmicas desempenhavam para os países europeus, esses viajantes tanto poderiam assumir um comportamento condizente com a sua própria experiência nos países estrangeiros quanto revelar a recorrência de padrões já conhecidos dos europeus, como aquele relacionado ao temor religioso. A julgar pelas imagens lascivas sobre o mensageiro do Islã circulantes desde o período medieval, poderíamos ver aberto aqui o terreno para a observação, descrição e divulgação das práticas sexuais dos povos do Levante, compreendendo-se também o espaço do harém.

A literatura de viagem se revela uma fonte em potencial para se pensar a história dessas imagens, porque circulava de forma intensa entre os ingleses e certamente entre os franceses. Como alega Hasan Baktir, "os livros de viagem e as cartas de viagem vendiam aos milhares" (BAKTIR, 2007, p. 24). Pelo aumento do público leitor, pelos preços baixos e pelo sucesso alcançado, é possível afirmar que esse gênero estava entre os mais populares no século XVIII, superando muitas vezes as próprias novelas (BAKTIR, 2007, p. 24). Mesmo antes, podem-se encontrar textos ao modo de best sellers. O relato do húngaro Bartolomej Georgijević, que registrava a sua experiência de treze anos de escravidão entre os otomanos, foi traduzido e reimpresso ao menos 88 vezes entre 1544 e 1600 
(MACLEAN, 2004, p. 4). Diante disso, o poder de representação cultural projetado por tal literatura ganhava destaque, sendo essas representações cruciais quando se busca um entendimento sobre o tratamento teórico dado ao Levante pelos europeus. Como espaço de produção e de recepção das imagens construídas pelos europeus, a narrativa de viagem poderá ser vista como uma síntese das representações que circulavam pela Europa ao longo do período moderno.

\subsubsection{Os viajantes íngleses}

"[...] before the English travelers met such people in the Eastern Mediterranean, they constituted only abstractions to him". Hasan Baktir (2010, p. 887).

É provável que um dos primeiros ingleses a viajar para o leste do Mar Mediterrâneo tenha sido um homem comum, não frequentador do ambiente real. Thomas Dallam (c. 1575-c. 1630), diferentemente de um grande número de viajantes ingleses do século XVII, não tinha no comércio o seu objetivo principal. Foram as suas habilidades como construtor de instrumentos musicais que cativaram, primeiramente, a rainha inglesa e, depois, o sultão otomano. A rainha Elizabeth I (1533-1603) havia ficado tão impressionada com um instrumento musical construído por ele, que resolveu mandar igual presente ao imperador otomano, Mehmet III, que governou entre 1595 e 1603. A entrega do instrumento musical como presente ao sultão ocorria em um momento em que a rainha inglesa 
buscava o apoio dos turcos contra os seus inimigos cristãos do Reino da Espanha ${ }^{18}$.

Pouco se conhece a respeito da vida de Dallam. Pela lápide de seu filho, em New College, Oxford, sabe-se que ele era natural do vilarejo de Dallam, em Lancashire (BENT, 1893, p. xvi). A partir de escassas informações encontradas na obra de Gerald MacLean e também na Enciclopédia Britânica, pode-se afirmar sobre o seu envolvimento com atividades artesanais e braçais, ainda que se encontre uma defesa sobre as origens distintas de sua família, a qual teria se dedicado a construir órgãos musicais (BENT, 1893, p. xix). Além de construtor de instrumentos musicais, Dallam tornou-se membro de uma associação de ferreiros, a Blacksmiths' Company, e mais tarde desempenhou função como alugador de cavalos. Um dos instrumentos musicais feitos por ele havia sido idealizado a pedido do King's College, cuja construção ocorreu entre 1605 e 1606 (BENT, 1893, p. xvii).

Como lembra MacLean, Dallam não tinha muito conhecimento anterior sobre a região que visitaria e, além disso, embarcou às pressas. Essas razões poderiam levar a contribuições genuínas do pensamento de um europeu sobre o Império Otomano. De fato, a visão de Dallam raramente evocava uma ideia apriorística sobre o que ele encontraria em sua viagem (MACLEAN, 2004, p. 112). Por não ser um cavalheiro educado à maneira clássica, nem estar a serviço da diplomacia ou do conhecimento bíblico,

\footnotetext{
${ }_{18}$ A encomenda e a entrega do presente ao sultão otomano simbolizavam tanto a busca por uma aliança política na guerra contra os cristãos da Espanha quanto a necessidade de alargamento das relações comerciais motivadas pela Levant Company, fundada em 1581. Sobre isso, ver Wood, 1935.
} 
o seu texto pode nos revelar elementos que não conheceríamos de outra forma (MACLEAN, 2004, p. 7).

Thomas Dallam embarcou em direção ao Império Otomano em fevereiro de 1599. Quando o navio chamado Hector [Heckter] chegou a Gallipoli (península no nordeste da atual Turquia), embarcou também Thomas Glover, futuro embaixador britânico em Istambul. Ao contrário de Glover, Dallam não devia possuir conhecimento da língua turca ${ }^{19}$. Isso pode ser concluído a partir do trecho em que ele afirmava sobre o seu "intérprete" (DALLAM apud BENT, 1893, p. 75). O resultado da sua viagem foi transformado em livro, recebendo o título A brefe Relation of my Travell from the Royall Cittie of London towardes the Straites of Mariemediteranum, and what hapened by the waye. As suas experiências de viagem foram registradas mês a mês, de modo que os eventos podem ser lidos na sequência temporal. O viajante não deixou assinalada qualquer expectativa em relação ao que esperava encontrar lá. Do mesmo modo, não chamou a atenção, no início de seu texto, para o harém ou para o serralho do sultão. Por tal razão, é possível que, caso ficasse admirado do palácio e das mulheres do sultão Mehmet III, concedesse algum destaque à cena observada.

Como já se pôde notar nas definições dos dicionários, "serralho" era o termo amplamente empregado pelos autores e possuía uma significação mais abrangente, indicando o palácio dos imperadores do Levante. A palavra faz alusão tanto ao serāi, em turco, quanto a sarāi, em

19 Glover havia vivido durante muitos anos em Istambul, e possuía um "perfeito entendimento" acerca da língua e das leis turcas (WOOD, 1935, p. 80). 
persa, visto que, nesse último caso, pode se referir a palácio, à estalagem e à hospedaria (NIMER, 2005, p. 269); já harém, que remete à palavra harām em árabe, originando o haremlik em turco, indica o espaço particular do convívio feminino dentro do palácio ou da casa (p. 84). Nesse momento de produção das narrativas, o termo serralho podia tanto remeter ao palácio quanto ao espaço feminino dentro do palácio. Nas narrativas de viagem do século XVII, serralho era mais empregado do que harém.

Portanto, ainda que houvesse uma fronteira fluida entre os termos harém e serralho, fato é que o espaço privado dentro dos palácios islâmicos se fazia conhecido dos europeus e não devia consistir em um tema estranho a Thomas Dallam. A imagem que teve o construtor de instrumentos musicais antes de acessar o serralho foi aquela da mulher islâmica no espaço das ruas. Ao passar por Argélia, Dallam fez alusão tanto às turcas quanto às mouras. Diria ele que todas andavam com as suas faces cobertas, assegurando ser comum encontrar quem acreditasse ou pensasse que tais mulheres não possuíam alma. Ele encerrava afirmando que seria bom para elas caso não tivessem alma, pois nunca iam à igreja [churche] ou às orações com os seus maridos (DALLAM apud MACLEAN, 2004, p. 15-16).

Embora tivesse escrito tal tipo de observação, o que se percebe é que a visão de Dallam sobre a sociedade islâmica, de uma forma geral, não era construída pela ótica dos ensinamentos religiosos, tampouco afeita a lições de cunho moralista. Por isso, não será uma tônica do autor tomar a posição de autoridade religiosa ante os muçulmanos, muito menos lançar incitamentos a respeito de comportamentos adequados a um inglês vivendo em 
uma sociedade desconhecida. De todo modo, sua declaração sobre as mulheres, acompanhando a afirmação de MacLean, logo seria disseminada a todas as mulheres estrangeiras (2004, p. 16).

Dallam desembarcou em Istambul em agosto de 1599. A sua chegada à capital do Império Otomano era já um indicativo de como o inglês empregava o termo "serralho". O artesão indicava que se avistavam as "Sete Torres" ou o primeiro porto antes de se alcançar o serralho [surralia]. O serralho era tomado, portanto, como uma construção física ou, mais especificamente, como o palácio do Grão-Senhor turco (DALLAM apud BENT, 1893, p. 57). A palavra era grafada tanto com "s" minúsculo quanto com "s" maiúsculo, e aparecia sob duas formas: surralia e surralya. As grafias Surraliae e Surraliao apareceram uma única vez.

A fim de instalar o instrumento musical, Dallam conseguiria permissão para frequentar o palácio real ao longo de um mês. O viajante chamava a atenção para o fato de os portões do palácio serem fechados rapidamente para que ninguém entrasse ou saísse dali sem o consentimento de um "turco corpulento", certamente, o guarda do portão. No segundo portão, o seu intérprete precisou informar ao guarda o que eles fariam no palácio, ou, como escreveu Dallam, "a nossa atividade”. Pelo período de um mês, Dallam afirmou ter jantado "todos os dias no Serralho", apreciando as uvas que lhe eram oferecidas após a carne.

Ao entrar no serralho, termo que o viajante definiu como "Corte do Grão-Senhor" (DALLAM apud PENZER, 1952, p. 32), Dallam escreveu que esse lugar parecia mais uma igreja do que uma casa. $\mathrm{Na}$ sequência, ele 
afirmava que "não se tratava de uma moradia qualquer, era uma casa do prazer" (DALLAM apud BENT, 1893, p. 62), mas também uma "casa da violência”, já que o imperador havia mandado matar dezenove irmãos e mais de vinte irmãs. Todos haviam sido estrangulados por surdos-mudos, cujo emprego na Corte Otomana era bastante comum. Neste "palácio de atrações luxuosas e perigos implícitos" - como escreveu MacLean -, Dallam logo começou a pensar que a sua liberdade estivesse em risco, demonstrando esse sentimento adiante.

Após a sua apresentação musical e o sucesso alcançado, Dallam foi levado cada vez mais para o interior do serralho de Mehmet III. E o que ele passou a vislumbrar a partir dessa incursão deixou-o maravilhado, como se estivesse em "outro mundo". Aqui, Dallam pôs em destaque a prerrogativa que lhe havia sido conferida, ou seja, a possibilidade de entrar no serralho do sultão, privilégio que nenhum outro cristão havia obtido (DALLAM apud KAMPS; SINGH, 2001, p. 66). Alegação similar será encontrada na obra do médico William Lempriere em sua viagem ao Marrocos em 1789, narrativa que será discutida no Capítulo 4. Após o sucesso da nova apresentação, Dallam foi convidado a permanecer no império para sempre. Ao dizer que tinha esposa e filhos que aguardavam por seu retorno, foram ofertadas mulheres do próprio harém de Mehmet, dentre as quais Dallam poderia escolher as melhores.

Ao caminhar pelo serralho, Dallam conheceu câmaras privadas do senhor otomano e pôde ver algumas de suas concubinas. Embora a parede fosse protegida com ferro, ele conseguiu avistar trinta concubinas do sultão em 
um jogo de bola. O viajante descreveu seus cabelos trançados a pequenas pérolas, caindo-lhes pelas costas. Em princípio, Dallam pensou se tratarem de rapazes [yonge men], mas depois percebeu que eram mulheres e muito bonitas [verrie prettie]. Ele ficou fascinado com o que viu. As roupas que elas usavam - continuava o autor - eram "brancas como a neve" (DALLAM apud PENZER, 1952, p. 167) e finas como a musselina, o que lhe permitia ver a sua pele (DALLAM apud MACLEAN, 2004, p. 45). Algumas, ainda, estavam com as pernas nuas, adornadas com um anel de ouro. $\mathrm{O}$ autor olhava com tanto interesse as mulheres no palácio, que o seu guia ficaria muito bravo com ele [verrie angrie]. O fato é que o viajante se sentia maravilhado diante deste cenário, como ele mesmo notara (DALLAM apud PENZER, 1952, p. 167). Mesmo diante desse panorama, o artesão recusou a oferta de permanecer no palácio e embarcou de volta para a Inglaterra, em 28 de novembro.

A admiração genuína de Dallam pelas concubinas é o único episódio que se aproxima do tema das habitações femininas dentro do palácio otomano. $\mathrm{O}$ autor não prolongou esse assunto, nem se ocupou em discutir conceitualmente este lugar. É importante lembrar que, ao falar sobre tal episódio para o seu intérprete, este o aconselhou a não contá-lo a mais ninguém; nenhum turco deveria ouvir essa história (DALLAM apud BENT, 1893, p. 75). Esse fato reforça o caráter de proibição a que o harém e as mulheres do governante otomano estavam sujeitos. Além disso, a sua atração pelas mulheres do Grão-Senhor não poderia gerar maior impacto entre os leitores europeus, ao menos por uma razão: Dallam decidiu não publicar o 
registro de sua viagem. Como nos lembra MacLean, a sua narrativa ficou desconhecida do grande público até 11 de novembro de 1848, quando o manuscrito foi comprado pelo Museu Britânico, adquirido de um colecionador, Henry Rhodes.

Ao contrário de Thomas Dallam, William Biddulph publicou o seu livro, relatando as suas experiências de viagem. A data de sua chegada a Istambul é imprecisa, mas, de acordo com MacLean, ele pode ter desembarcado na cidade entre outubro de 1601 e o início de 1607 (2004, p. 75$)^{20}$. O texto que veio a público não deixava entrever o seu nome. $\mathrm{O}$ autor preferiu adotar um pseudônimo, alegando que o livro fora publicado contra a sua vontade. Por certo, Biddulph, enquanto representante da Igreja protestante, ficara temeroso acerca de possíveis consequências da publicação da obra, já que relatos de viagem pareciam não gozar do mais alto posto na hierarquia literária. Alie-se a isso o fato de que escrever sobre os seus contemporâneos não consistia em uma situação confortável.

O relato de sua viagem foi construído a partir das cartas que Biddulph enviava para o seu irmão, Peter. A edição de seus textos veio a público em 1609, sob o título The Travels of certain Englishmen into Africa, Asia, Troy, Bythnia, Thracia, and to the Blacke Sea. Para MacLean, Biddulph parece ter sido o primeiro capelão inglês a publicar um texto sobre o Império Otomano. Se Thomas Dallam não se mostrara preocupado nem com a divulgação de sua viagem, nem com a moralidade inglesa, Biddulph,

${ }^{20}$ No texto mesmo de William Biddulph, aparece a informação de que a viagem iniciou-se em 1600 e terminou em 1609 (PARKER, 1999, p. 83). 
ao contrário, construirá suas observações orientando-se pela sua função religiosa. São encontrados n'As Viagens mais elementos de ordem retórica do que factual; uma espécie de guia com formas de conduzir uma alma protestante em locais "estranhos e ímpios" (MACLEAN, 2004, p. 53). Mais do que isso: um libelo em favor do rei inglês, dos ministros da igreja, dos maridos, da Inglaterra (p. 53).

O clérigo advertia sobre a corrupção a que estavam sujeitos os ingleses que viviam em terras estrangeiras. Mas não bastava permanecer distante destas culturas, havia perigo também em ler escritos sobre tais viagens, uma vez que os textos haviam sido contaminados pelos vícios estrangeiros. Diante disso, a edição de seu próprio livro seria uma forma de corrigir os erros que já circulavam pela sociedade inglesa. A sua crítica se referia à obra de um peregrino inglês, Henry Timberlake, em viagem à "Terra Santa", cuja publicação ocorreu em 1603. Biddulph alertava que informações erradas poderiam ter sido publicadas sem o consentimento de seu autor. Porém, ainda que fosse desse modo, o texto do "mestre Tymberley" possuía muitos erros. Para o clérigo, era, portanto, uma vergonha que este relato tivesse sido publicado (BIDDULPH, 1609 apud MACLEAN, 2004, p. 54).

O livro mesmo de Biddulph guardava vários mistérios. O clérigo não se revelou desejoso em publicá-lo e para tanto fez - seguindo possivelmente recomendações do editor - várias modificações no texto. Sob o pseudônimo de Theophilus Lavender, o autor não citava o nome do navio em que ele viajara, nem relatava ipsis litteris o percurso da viagem. Um elemento se revelava óbvio: a sua função nas terras estrangeiras. Biddulph serviria como 
exemplo de consciência moral aos expatriados ingleses, afinal, se a viagem de ingleses a territórios estrangeiros poderia ser uma forma de ganhar uma grande quantidade de dinheiro, poderia também ser uma oportunidade de escapar dos regramentos morais do país de origem. Eis a sua função de pregador para os mercadores ingleses que residiam em Alepo (MATEI-CHESNOIU, 2012, p. 173).

Biddulph teria viajado para o Império Otomano também para ajudar Henry Lello, o embaixador inglês em exercício, a estabelecer a primeira Igreja protestante por lá (MACLEAN, 2004, p. 68). Se a distância era longa e a jornada era penosa, ainda assim, o clérigo fazia questão de afirmar que, embora o ar houvesse mudado, ele permanecia o mesmo homem (BIDDULPH, 1609 apud MACLEAN, 2004, p. 71). Essa afirmação indica, de forma destacada, o possível caminho seguido por Biddulph e que ficou formalizado na edição de seu texto: o objetivo moral de seu relato é que deveria ficar registrado para que todos pudessem ler (MACLEAN, 2004, p. 74). Essa ânsia por moralizar e indicar os comportamentos retos dentro das concepções protestantes se construía em detrimento das outras religiões. Tal característica é muito latente em relação à narrativa de Thomas Dallam. Todo o texto de William Biddulph foi elaborado na tensão entre as premissas de que ele era porta-voz e aquelas das religiões católica, islâmica e judaica. Diante disso, cabe ressaltar que "muitos europeus no início da modernidade" não conseguiam imaginar um "mundo de diversidade religiosa" (COLLINS; TAYLOR, 2006, p. 2).

É possível pensar que boa parte de sua antipatia em relação aos turcos se dava por serem eles islâmicos. 
Biddulph afirmava que os turcos nada mais eram do que um grupo de soldados não pagos, cujo líder, Muhammad ${ }^{21}$, havia fundado uma nova religião baseada na expansão militar (BIDDULPH, 1609 apud MACLEAN, 2004, p. 86). O clérigo protestante, portanto, não fazia qualquer diferenciação entre muçulmanos - chamados de sarracenos e os árabes, ou entre estes e os turcos. Esta última situação pode ser observada quando o autor definiu o Islã como uma "crença 'turca' hibridizada; a religião do poder imperial otomano" (BIDDULPH, 1609 apud PARKER 1999, p. 86). Não é demais lembrar que muito da imagem deturpada de Muhammad disseminada por Biddulph vinha de cópia feita do livro The Policy of the Turkish Empire, de Giles Fletcher, publicado em 1597. Os elementos religiosos do Islã consistiam seguramente no maior incômodo do clérigo.

É certo que a fúria religiosa contra os muçulmanos refletiria na construção do seu relato, cedendo pouco espaço às observações sobre o palácio otomano e sobre a vida das mulheres islâmicas. A partir do texto reproduzido por Kenneth Parker, verifica-se uma única indicação do termo serralho na obra de William Biddulph. Ao escrever

21 Havia erros flagrantes na biografia de Muhammad assinalados na obra de William Biddulph. O local de nascimento do mensageiro do Islã é indicado por "Itraipia", e a sua mãe seria "Hadidja". Sabemos que Muḥammad nasceu em Meca [Makka], por volta de 570, e que a sua mãe se chamava Amina bint Wạ̣b. Não é possível afirmar que o clérigo quisesse indicar Yatrib, cidade para a qual o profeta se dirigiu em 622 em um processo conhecido como Hégira. Além disso, Biddulph assegurava que na juventude, em razão de sua pobreza, Muhammad teria vivido de roubos e assaltos (PARKER, 1999, p. 93). Karen Armstrong dirá, ao contrário, que quase não há fontes sobre a infância e a juventude de Muhammad (2002, p. 58). 
sobre a conquista de Constantinopla por Mehmet II, o clérigo inglês afirmava que este sultão havia sido o "primeiro fundador do Grande Serralho" (BIDDULPH, 1609 apud PARKER, 1999, p. 87). Ele adicionava que se tratava do local em que ainda residia o Grão-Senhor turco. A descrição física do palácio se estendia o suficiente para que o clérigo registrasse a beleza da construção, além de "uma suntuosa mesquita ou igreja, com um amarath e colégio" (p. 87).

As influências advindas de outros viajantes ao Levante não foram suficientes para que o clérigo desenvolvesse o tema do serralho ou harém. Embora Biddulph tenha se pautado na narrativa de viagem do géografo francês $\mathrm{Ni}$ colas de Nicolay (1517-1583), publicada em 1576 e intitulada Les navigations, peregrinations et voyages faicts en la Turquie, as suas pontuações não faziam sombra sobre o tema tratado com extensão pelo francês. Ainda que Nicolay discorresse sobre o tema do serralho - no sentido de palácio real - e apresentasse inclusive inúmeras gravuras sobre as mulheres islâmicas, isso não atraiu Biddulph ${ }^{22}$. $\mathrm{O}$ inglês estava mais interessado em corrigir erros vulgares, como a crença errônea de que o Mar Negro fosse negro ou de que o Mar Vermelho tivesse esta cor em razão do sangue de Moisés. As "correções" eram feitas ainda que ele próprio, muitas vezes, não tivesse presenciado a situação descrita. Biddulph confiava, então, no que havia sido escrito anteriormente.

Como o seu relato estava amplamente calcado nos valores moralistas e religiosos, houve um maior espaço dedicado a retratar os comportamentos femininos

22 A gravura sobre uma mulher turca em sua "maison ou Sarail" pode ser vista no "Anexo C" deste livro. 
muçulmanos. As suas reflexões em torno das sociedades islâmicas, contudo, oscilavam entre a reprovação e a indicação do caráter exemplar de certas situações. Como o autor viajou pelo Império Otomano e também por cidades árabes, as suas observações se referiam tanto aos turcos quanto aos árabes. Sobre os turcos, o clérigo chamava a atenção para o fato de os homens terem escravas, mantendo-as como esposas (BIDDULPH, 1609 apud MACLEAN, 2004, p. 88). No caso dos árabes, o inglês ressaltava o seu atraso, as suas características inalteradas. Afirmava ele que as esposas dos árabes "usam anéis em seus narizes", completando que "estas pessoas podem suportar e sofrem grande aspereza e miséria” (p. 94).

No item intitulado o "sétimo mandamento", Biddulph explicava de que modo se dava o casamento entre os muçulmanos. Aqui, o autor cometeu um engano ao declarar que um homem poderia tomar quantas esposas ele desejasse. Sem fazer qualquer comentário valorativo sobre a poliginia, o clérigo expunha brevemente o formato das relações privadas entre marido e esposa. Ele afirmava que uma mulher nunca se sentava à mesa para jantar com o seu marido. Além disso, nenhum homem acima de doze anos poderia ser admitido em sua casa. Por fim, elas nunca iam à rua sem a permissão de seus maridos, o que compreendia apenas as visitas aos banhos ou ainda aos túmulos (BIDDULPH, 1609 apud PARKER, 1999, p. 95).

Biddulph revelou a sua admiração ante o fato de (i) as muçulmanas servirem os seus maridos, (ii) reverenciá-los, beijando a sua mão sempre que eles entrassem em casa, e (iii) muito raramente saírem à rua. Se tais práticas existissem na Inglaterra, completava, "as mulheres seriam muito mais obedientes e fiéis a seus maridos do que muitas delas são" 
(PARKER, 1999, p. 95). Se estas situações poderiam ser consideradas matéria de aprendizado às mulheres inglesas, o mesmo, por suposto, não se aplicava à prostituição. Nesse caso, se houvesse punição para as prostitutas, menos prostituição existiria (PARKER, 1999, p. 95).

A posição de Biddulph diante de sua própria experiência - ou em relação ao que lera anteriormente -, era particularmente híbrida, ou mesmo confusa. Essa postura ambígua refletia, dentre outros fatores, o desconhecimento de Biddulph acerca da cultura e das línguas asiáticas. Como sugere MacLean, o clérigo deveria possuir conhecimentos elementares da língua árabe, turca e persa, uma vez que tais informações se faziam conhecidas através de conversas por ele testemunhadas (2004, p. 91-92). Portanto, as referências enviesadas, somadas às premissas religiosas conservadoras e aos vestígios marcadamente anti-islâmicos de origem medieval, ajudavam a compor um retrato negativo das sociedades islâmicas.

Diante disso, o texto do clérigo contribuía para fomentar generalizações que se faziam passar por observações pontuais sobre uma experiência vivida. Ao descrever os gregos de Alepo, Biddulph afirmava que, por serem muito pobres, as mulheres sustentavam a família através da prostituição de seu corpo; ele assinalava ainda que os seus próprios maridos levavam constantemente os clientes até elas (BIDDULPH, 1609 apud PARKER, 1999, p. 100). Esta poderia ser apenas mais uma observação, caso não se resumisse no essencialismo que o clérigo conferia às suas declarações (MACLEAN, 2004, p. 96). Ou seja, é provável que a licenciosidade sexual como característica das gregas fosse mais uma generalização pautada em boatos do que em observações propriamente ditas. 
Nesse sentido, a afirmação de um bispo inglês que viveu entre os séculos XVI e XVII é sintomática da relação entre a experiência empírica e o escrito de viagem. Diria Joseph Hall (1574-1656) que os livros poderiam fornecer tudo o que é indispensável para conhecer os territórios estrangeiros, já a viagem em si implicava uma desnecessária exposição a perigos, tanto físicos quanto espirituais (MACLEAN, 2004, p. 55). Biddulph deveria concordar com esta máxima, uma vez que, para ele, viver em países estrangeiros contaminava os homens que lá permaneciam (MACLEAN, 2004, p. 64). Não resta dúvida, portanto, de que tal tipo de julgamento interferia diretamente na concepção de uma narrativa de viagem.

Por tal razão é que Biddulph será considerado por MacLean como um precursor do Orientalismo. Afinal, tratava-se de alguém que se via com autoridade para falar sobre o Oriente, sustentando como este era tão diferente de todas as origens antigas que lhe eram referências na Europa, ainda que tantas vezes o que se registrava em texto não correspondesse à realidade. Ou seja, já se poderá encontrar em Biddulph algum grau de representação enviesada do muçulmano, a qual não somente destacava a diferença em relação aos europeus, mas também o inseria em um padrão hierárquico. Esse caráter "especializado" do europeu para tratar o oriental desembocaria, como escreveu Edward Said, na afirmação sobre a imutabilidade do Oriente ${ }^{23}$.

23 É certo que Said também considerava o Orientalismo um campo de estudos sobre o Oriente, cuja produção era feita por estudiosos "genuinamente interessados" nas várias possibilidades temáticas. A crítica feita por ele é em relação a um dos pressupostos do Orientalismo que enxergava 
Uma vez que estava imbuído de sua missão religiosa, o clérigo inglês estava sempre atento a quaisquer práticas ou comportamentos morais e sexuais reprováveis. Percorrendo o seu texto, é possível verificar um momento de relativo destaque em relação a esse tema. Trata-se de uma caracterização sexual do Levante referente à tomada de Constantinopla pelos otomanos, em 1453 . O clérigo revelava o seu desconforto acerca desse fato porque, durante tal processo, Mehmet II violentara "a esposa do imperador, filhas e outras senhoras de honra, com uma crueldade selvagem". Nenhum "tipo de fornicação, sodomia, sacrilégio ou crueldade" havia deixado de ser executado por eles (BIDDULPH, 1609 apud PARKER, 1999, p. 86). A vinculação dos islâmicos à manifestação sexual exagerada era ainda lembrada pelo clérigo quando ele mencionou as diferenças políticas entre o governo da Inglaterra e os governos do Levante. Ele declarava que, se os ingleses estivessem neste "país selvagem", saberiam o que "é viver em uma comunidade Cristã, sob o governo de um rei piedoso, que governa pela lei e não pela luxúria” (BIDDULPH, 1609 apud MACLEAN, 2004, p. 97).

Nos textos de viagem, é possível encontrar uma fina trama que se compõe a partir dos direcionamentos da política europeia, dos interesses particulares dos viajantes e do tipo de relação que se estabelecia entre estes e a sociedade visitada. É neste último elemento que se abre espaço tanto às experiências empíricas do viajante quanto a um cenário difuso, povoado de informações nem sempre

\footnotetext{
"um Oriente imutável" e, portanto, "absolutamente diferente do Ocidente" (SAID, 1990, p. 145).
} 
comprovadas. Tal cenário podia abarcar prejulgamentos, notícias veiculadas por outros viajantes, ou por outras obras impressas, assim como narrativas orais, imagens, considerações formadas no entrecruzamento entre o evento visto e aquele imaginado.

Foi justamente a desconfiança em torno desse escopo prévio, aliada a um conjunto de interesses particulares, além de motivações inglesas, que fizeram o advogado inglês Henry Blount (1602-1682) - frequentador da Corte de Carlos I (1600-1649) - iniciar a sua viagem. O seu livro, A Voyage into the Levant, foi publicado em 1636. Ele chegou a Istambul no verão de 1634 e em seguida foi para o Egito, ou, como ele chamava, "O Grande Cairo" 24 . O livro o aclamou de tal modo, que ele seria chamado pelo rei Carlos I para compor um grupo das primeiras famílias de cavalheiros do reino (MACLEAN, 2004, p. 121). O seu trabalho consistia em assessorar o reino inglês em matéria de comércio e de navegação. Então, é certo que se devia tratar de um homem influente na Corte. Mas isso não o impediu de buscar informações e situações que o motivavam particularmente. Dentre estas razóes, estava o seu interesse em saber se os turcos estavam aptos a confrontar os cristãos (BLOUNT, 1636, p. 2).

Pelo número de edições e traduções da obra, pode-se acreditar que o livro de Henry Blount tenha seguido os passos de sucesso e de prestígio de seu autor. A obra foi reimpressa sete vezes antes de 1671 . Além disso, houve

24 Para Henry Blount, o Egito era “a fonte de todas as ciências e das artes civis” (1636, p. 3). Não é possível afirmar com precisão, mas Blount deve ter chegado ao Egito por volta de novembro de 1634 (p. 102). 
uma tradução para o alemão em 1687 e uma edição ilustrada holandesa publicada duas vezes: em 1707 e em 1737 (MACLEAN, 2004, p. 122). A própria edição inglesa (1636) foi publicada rapidamente, uma vez que a viagem de Blount se iniciou em maio de 1634 e durou onze meses (BLOUNT, 1636, p. 5).

A afirmação inicial ressaltada por Blount era já sintomática do questionamento em relação às ideias produzidas e disseminadas sobre os turcos até então. Perguntava ele: o "jeito turco parece realmente bárbaro, como nos é dado a entender, ou seria outro tipo de civilização, diferente da nossa, mas não menos simulada"? (1636, p. 2). Como um possível porta-voz do discurso isento, Blount queria investigar o peso desta afirmação que ele não justificava de onde vinha, nem por onde circulava. A julgar pela questão colocada anteriormente, é certo que o advogado dava aos turcos o benefício da dúvida e partia para Istambul em busca de respostas.

Nesse sentido - e ao contrário do que fizera o citado clérigo William Biddulph -, Henry Blount se negava a fazer uso de registros de viagens anteriores. Ele chegou mesmo a insistir junto a um amigo seu, antiquário, sobre a sua “experiência e observação cuidadosa" (MACLEAN, 2004, p. 127). Argumentaria ele que os "relatos não são apenas em grande parte falsos, como relacionados a informações erradas, presunçosas ou interesseiras" (BLOUNT, 1636, p. 3). Portanto, ele não poderia se pautar em tal conhecimento e deveria, de outro modo, buscar informações a partir do que ele próprio visse.

A sua passagem por Istambul foi durante um período turbulento, com disputas entre janízaros (soldados de 
elite) e sipahis (integrantes da cavalaria de elite), em meio ao sultanato de Murad IV (1612-1640). Blount estava interessado no comércio internacional, daí que o seu texto seria construído tendo-se esta preocupação como causa motora. Metáforas matemáticas, como aquela que colocava o Império Otomano como o centro da circunferência, e a apreensão deste império através da geometria ou da aritmética, seriam constantes. O que importava era saber o tamanho dos exércitos otomanos, as fortificações de suas cidades, o esplendor da arquitetura, a distribuição da população, a geografia de sua capital (MACLEAN, 2004, p. 126). Blount estava convencido de que Istambul era o lugar ideal para comandar o mundo.

A viagem para o Império Otomano não possuía qualquer cristão além do próprio Blount. Antes de iniciar a viagem, Blount tomou um janízaro em Veneza - possivelmente o seu intérprete ao longo da viagem - para abastecê-lo com comida, cavalos, um possível condutor de cavalos e o que ele chamou de "passagem" até Istambul (1636, p. 5). Em sua estadia no Império Otomano, o viajante preferiu adotar vestimentas turcas, conversar com mulheres e crianças, e evitar viagens com compatriotas e com outros cristãos. Isso tudo fazia parte de sua "estratégia de viagem". Tais informações, somadas àquelas que pudemos notar nos viajantes anteriores a ele, atestam as várias compreensões sobre o que seria uma viagem ao Levante ${ }^{25}$. Aqui, faz-se necessá-

25 Blount não afirmava ter sido enviado pelo governo inglês para "espionar” o Império Otomano. De todo modo, ao apontar as características necessárias a tal função, Thomas Palmer (1540-1626), um contemporâneo seu, diria que é possível encontrar muitos de tais requisitos em Blount (MACLEAN, 2004, p. 129). 
rio notar que Blount não apenas se posicionava em favor do Império Otomano na corrente guerra contra a Polônia, como assinalava que os ingleses honravam as "ações gloriosas [dos turcos] no mundo", visto que estes eram também amados em razão do tipo de comércio praticado por eles (BLOUNT, 1636, p. 15).

Mais do que isso. Blount nos leva a entender que havia sido convidado a lutar na guerra ao lado dos turcos. Nesta matéria, ele deixava explícito o histórico de ligação entre a Inglaterra e o Império Otomano (1636, p. 15), o que demonstraria certamente o seu apoio aos turcos. Mas ele afirmaria adiante que não poderia se engajar na guerra, pois, com muita tristeza, reconhecia a sua incapacidade. Isso se devia ao seu desconhecimento da língua turca, o que impediria que ele acatasse os comandos, assim como poderia envolvê-lo em algum tumulto, uma vez que ele não conseguiria expressar as suas posições.

Assim como os seus compatriotas Thomas Dallam e William Biddulph, Blount também não fazia uso do termo harém. A palavra "serralho" apareceu uma única vez no seu texto e também indicava o significado físico. $\mathrm{O}$ autor afirmava ter entrado na Segunda Corte do palácio que era caracterizada pelo "claustro baixo" [low Cloyster] e por "muitos pilares pequenos" [many small pillars]. Dentro dessa construção, Blount assegurava não ter visto nada além de um grande número de oficiais e atendentes, todos em silêncio e em reverência "tão maravilhosos", que indicavam o temor diante do soberano. Seguia-se daí uma série de descrições sobre a arquitetura turca que o viajante contemplava. 
Blount não se estendeu sobre este assunto. $\mathrm{E}$ a abordagem sobre a sexualidade islâmica se revelava a partir de outro elemento. Logo no início de sua narrativa, o viajante afirmava que dentre os seus objetivos estava averiguar se, no momento em que o "Grande Cairo" fora tomado pelos turcos, podia-se identificar nesse processo uma "sensualidade ébria” (BLOUNT, 1636, p. 3), como acreditavam muitos cristãos. Porém, mais adiante, o autor afirmaria que um dos "atos políticos" do Alcorão era a proibição do vinho (p. 82). Portanto, o que se percebe no desenvolvimento de seu texto é o abandono do fator alcoólico em favorecimento da sexualidade manifestada entre os turcos.

É preciso lembrar, contudo, que mesmo a sexualidade não se resumiu em um amplo tópico dentro de seu relato. Os comentários sobre as mulheres muçulmanas passam quase despercebidos no meio de sua investigação sobre o comércio ou sobre o exército otomano. Ao mostrar como os turcos iam à guerra, Blount relatava o fato de os generais levarem consigo "doze ou dezesseis" esposas. Entretanto, o viajante não concederia maior destaque a tal episódio. Blount citaria, por fim, um assunto que aparecerá com frequência nos próximos viajantes-autores: a disseminação da homossexualidade masculina entre os turcos.

No episódio sobre a comitiva levada para a guerra, Blount assinalava dois pontos relevantes para o tema aqui tratado. Ele afirmava que os próprios turcos haviam contado a ele que os baxás usavam as suas esposas com vistas às atividades domésticas [para vesti-los e lavar as roupas] e para a sua reputação [reputation]. Ainda neste item, o viajante assegurava que os oficiais turcos tinham "provavelmente mais Catamitos, que são os seus amores sérios” (BLOUNT, 1636, 
p. 14). A palavra catamito tem origem no latim catamitus e faz referência a um jovem rapaz tomado como objeto sexual (BONFANTE; BONFANTE, 2002, p. 110).

A complexidade das relações sexuais dentro dos palácios islâmicos era matéria recorrente nos relatos de viagem. O cenário luxurioso era visto por certos autores europeus como um dos grandes motivos da decadência política dos Impérios Otomano e Persa, como notaremos adiante. $\mathrm{O}$ fato é que o harém era tomado por esses autores como o centro do império, como se dali emanassem as decisões que influenciavam a condução da administração política. Não eram apenas os encontros sexuais entre o governante e as mulheres que levariam ao colapso dos impérios islâmicos. Os vínculos eróticos que se estabeleciam entre os oficiais do Estado e os jovens rapazes eram também responsáveis por tal situação.

O sargento e tradutor Edward Grimestone (morto em 1640) foi um dos autores a conferir destaque a este tema. Ao escrever a apresentação do livro que ele traduzira para o inglês, Grimestone assumia que o Estado do Grão-Senhor turco era de grande altivez e a "monarquia mais poderosa do mundo" (1635, p. iii). Contudo, na mesma medida, era possível encontrar na Corte Otomana a tirania e a concupiscência, o que a levaria à decadência (MACLEAN, 2004, p. 148). A influência na construção desse tipo de pensamento tinha origem certamente nas ideias do autor traduzido, no caso, Michel Baudier. Em sua publicação de 1624 sobre o serralho otomano, o francês sustentava que o sultão possuía grande paixão por meninos, que, com a sua beleza e graça, alimentavam esses prazeres. 
Henry Blount, a se guiar pelo princípio da desconfiança acerca dos autores que o precediam, não explorou as relações sexuais como um caminho certo em direção à ruína política. Sobre o episódio dos meninos que serviam os baxás e o sultão, Blount fazia um breve comentário, alegando que no Levante a sodomia não era tomada como vício $(1636$, p. 79$)$. MacLean aventa outra possibilidade para explicar o pouco destaque concedido à homossexualidade no exército otomano: o texto de Blount poderia indicar em alguns momentos certa simpatia pelas relações homoeróticas (MACLEAN, 2004, p. 151). Não se pode encontrar na narrativa, entretanto, qualquer elemento explícito que justifique tal tese. Havia somente o registro do episódio em que, após receber sorvete, Blount oferecia um espelho de bolso a um dos jovens favoritos do sultão Murad IV, em troca de adentrar a tenda do governante $(1636$, p. 14).

No livro de Blount, o serralho como sinônimo de palácio imperial era construído a partir de um destaque maior à participação de jovens rapazes e não à presença das mulheres do sultão. Considerando as observações feitas sobre as relações entre o sultão e os jovens rapazes ao longo de seu livro, é provável que esse cenário tenha causado maior impacto sobre a sua experiência de viagem. É preciso lembrar aqui a observação de Everett Rowson que afirma não ser considerado homossexual o homem adulto que mantivesse papel de penetrador de mulheres ou de jovens rapazes (1991 apud PEIRCE, 2009, p. 1331). De todo modo, não se notará no livro de Blount qualquer termo relacionado à homossexualidade quando o viajante se referia aos sultões e a outros políticos turcos ${ }^{26}$.

\footnotetext{
26 A palavra "homossexual" passou a ser usada na Europa somente a partir do século XIX (TAMAGNE, 2006, p. 6).
} 
Antes de Blount, já se podiam encontrar referências impressas sobre as relações homoeróticas na Corte Otomana. Nos três volumes de viagem do inglês Fynes Moryson (1566-1630), publicados em 1617, o autor se referia a uma "geral avidez e licenciosidade dos soldados" turcos (1908, vol. 4, p. 120). Antes de Moryson, o poeta e viajante inglês George Sandys (1577-1644), em passagem pelo Império Otomano no ano de 1610, ressaltava as relações eróticas entre o sultão e os jovens rapazes. Afirmava ele que, no momento em que estivera lá, o sultão Ahmed I (1590-1617) havia levado oito de seus pajens a um "Mar de Sodomia" que consistia em um "crime ordinário, se estimado como crime, nesta Nação” (SANDYS, 1615, p. 73).

A ausência de considerações valorativas sobre as relações sexuais entre homens e rapazes turcos estava em consonância com a postura adotada por Henry Blount ao longo de sua viagem. Ele desconfiou de julgamentos prévios sobre os turcos e chegou a conclusões positivas sobre essa sociedade. Diante disso, os turcos seriam descritos como o povo mais cortês em suas saudações, tomado de "honra, virtude e conhecimento" (1636, p. 83). O "jeito turco", que Blount procurava desvendar no início de sua viagem, abarcava estes adjetivos, além da riqueza e do poderio militar. Mas não é menos certo que a sensualidade, $\mathrm{e}$ mesmo a luxúria, também pudessem defini-lo.

Pouco mais de uma década separaria a viagem de Henry Blount da viagem feita por um comerciante inglês pelo Norte da África. O texto de T.S., feito cativo na Argélia, ressaltava outra face da literatura de viagem. Como defende MacLean, o seu livro oferecia "um padrão de narrativa extremamente adequado para as fantasias nacionalistas de seu momento histórico" (2004, p. 181-182). O autor, 
cuja identidade permanece um mistério ${ }^{27}$, começou a sua viagem em julho de 1648 , e a sua obra, que levanta suspeitas sobre o que era realidade e o que era ficção, deve ser lida à luz das relações de poder do Império Otomano no Magrebe, assim como dos interesses econômicos e pessoais dos ingleses nesta região.

Diferentemente dos três viajantes ingleses analisados até o momento, T.S. informava que, na obra As Aventuras [The Adventures of $M^{*}$ T.S.], o leitor encontraria observações úteis adornadas com as "mais agradáveis aventuras". Afora a própria condição de cativo, as aventuras vividas por T.S. compreendiam lutas armadas, acordos políticos e episódios de cunho sexual. Ainda que fosse assim, o termo "harém" continuava ausente das narrativas inglesas. Nesse caso, nem mesmo a palavra serralho seria empregada.

A viagem para o Norte da África não era uma intenção declarada de T.S. Como se verifica no início de sua obra, o autor estava já inclinado a abraçar o emprego de mercador quando foi surpreendido pela morte do pai e depois pela do irmão. Como eles lhe haviam deixado uma herança, T.S. resolveu embarcar no fim de julho de 1648 no navio chamado Santa Maria, em uma viagem de negócios. Primeiro, T.S. alcançou o Cabo de São Vicente [extremo sudoeste de Portugal], e em seguida ele teria de seguir para Cádiz [sul da Espanha], onde deveria descarregar algumas mercadorias (1670, [s. p.] $)^{28}$.

\footnotetext{
${ }^{27}$ Embora Nabil Matar assinale que T.S. poderia ser abreviatura de Thomas Smith, Gerald MacLean alega que não é possível fazer tal afirmação com autoridade (VITKUS; MATAR, 2001, p. 45; MACLEAN, 2004, p. 179-180). ${ }_{28}$ The Adventures of (Mr. T.S.), an English Merchant Taken Prisoner by the Turks of Argiers (T. S., 1670). Edição eletrônica da Universidade de Chicago. Disponível em: < http://penelope.uchicago.edu/TS_Africa >
} 
Ainda no Cabo de São Vicente, o navio de T.S. seria surpreendido por um navio turco. Uma vez que possuíam munição, os cerca de cem homens do navio Santa Maria passaram a lutar contra os turcos. Embora estivessem feridos, eles "resolveram morrer com as suas armas nas mãos" no lugar de desistir do embate. A tripulação do navio em que estava T.S. teve o seu número reduzido para dezoito homens, sendo o próprio navio atingido por um "grande tiro". Em seguida, os turcos, temerosos de que o mar pudesse arrastá-los, decidiram embarcar os homens restantes, apossando-se da rica mercadoria que o navio carregava. T.S. foi tomado como cativo, sendo levado para a Argélia.

A descrição do que os outros viajantes ingleses nomeavam de serralho aparecerá em T.S. simplesmente como "palácio". Após chegar a Argel, T.S. seria conduzido ao "Palácio do Rei". Lá - relatava o viajante -, ele e outros prisioneiros passaram pela primeira guarda e alcançaram uma "grande e espaçosa Corte pavimentada com pedra de mármore branca”. Em um vasto salão, os cativos esperavam a entrada do "Rei de Argel". O rei, contudo, ainda não havia chegado, uma vez que ele tinha ido ao banho e depois tomaria outra "recreação", como era habitual nos climas quentes.

O tema das relações homoeróticas masculinas também será marcado em T.S. Ele afirmava ser surpreendente "ver como eles são apaixonados por homens bonitos". Possivelmente por essa razão é que MacLean enxergou na escravidão de T.S. uma "crise de gênero", uma situação que colocava "a sua masculinidade em questão" (2004, p. 187). No palácio, T.S. seria empregado como cozinheiro, 
mas, após um incidente com a preparação de um prato, ele perderia essa função. Foi, então, que T.S. conseguiu emprego como guardião do banho no mesmo lugar.

Nesta função, uma das mulheres do rei se interessou por T.S., buscando fazer uso do banho quando o soberano não estivesse presente. $\mathrm{O}$ autor lembrava que havia sido mais respeitoso com ela do que ela desejava, pois a deixou aos cuidados de suas escravas. A situação chegaria aos ouvidos do governante, e T.S. perderia o seu posto no palácio real. O viajante, então, seria levado ao mercado de escravos - por ordem do rei - e comprado por um novo senhor. Na realidade, tratava-se de uma nova senhora, já que o nosso autor escravo seria adquirido pela esposa do rei, a mesma que o seduzira anteriormente.

Os comportamentos de T.S. - ou as construções feitas por ele - nos levam ao encontro de uma observação de MacLean: os europeus renegados agiam da maneira como pensavam que os "turcos" se comportavam (2004, p. 195). Ou seja, T.S. - com as ressaltadas insinuações sexuais, banhos no clima quente e aventuras no palácio imperial -, retratava não somente o que ele havia vivido, mas também o que os leitores ingleses esperavam ler. Essas predisposições sexuais - ainda que não estivessem circunscritas somente ao espaço do harém - ganhavam destaque na literatura deste momento. $\mathrm{O}$ que se verifica na narrativa de T.S., portanto, é que o apelo sexual colado aos muçulmanos, e em particular ao Norte da África, era evidente. Como lembra Aimillia Ramli, não sem motivo um dos argumentos usados pelos escritores deste período para explicar a filiação dos "cristãos renegados" ao Islã era o fato de que esta religião propiciava um ambiente de maior liberdade sexual aos seus adeptos (RAMLI, 2009, p. 47). 
É justamente isso que é mostrado na sequência do texto. T.S. permaneceu escravo de tal senhora por dois anos. Nesse tempo, a mulher tornou-se devota de tal maneira, que passou a frequentar a mesquita com grande assiduidade. Em virtude da constante presença nas orações públicas, a senhora adquirira grande estima do povo e mesmo de seu marido, sendo designada como santa. Não se tratava de mera devoção, mas também de lubricidade, uma vez que havia uma passagem secreta entre a mesquita e os alojamentos de T.S. O desfecho dessa história, contudo, seria trágico. Outra esposa do sultão envenenaria a amante de T.S., causando a sua morte, o que levaria o autor a lamentar os infortúnios da vida servil à qual estava entregue. Depois disso, ele seria escravo de um mestre jardineiro, de um renegado inglês e de um renegado italiano, até ser comprado por um oficial da milícia chamado Hally Hamez Reiz.

Nesse momento da narrativa, T.S. nos dá uma pista importante sobre como enxergava a vida reclusa das mulheres islâmicas. Para ele, o fato de as mulheres se manterem frequentemente em casa fazia com que a sua mente e as suas afeições vagassem para longe dali. Caso tivessem "tanta liberdade quanto em outros países, elas não seriam tão furiosamente debochadas”. Quanto mais as mulheres eram proibidas e impedidas do que T.S. chamou de "variedade", mais prazer e satisfação elas encontrariam nessas múltiplas possibilidades amorosas. Uma de tais possibilidades era inclusive o próprio T.S., já que ele receberia presentes de uma senhora casada cujo nome ele não revelou. Diante do que vivera até este momento, T.S. afirmava que, se o seu projeto fosse "fazer conquistas no 
Império do Amor”, ele pensava que ninguém poderia ter sido mais feliz.

Dada a natureza das aventuras sexuais de T.S., MacLean afirma ser difícil não pensar que há nelas uma dose de imaginação. Para ele, não fosse pelas detalhadas descrições históricas e topográficas, poderíamos "suspeitar que [o texto d'] As Aventuras como um todo foi fabricado" (2004, p. 199). Há sim a presença de um cenário extraordinário em T.S. que não encontramos nas outras narrativas lidas até o momento. Ao acompanhar o exército otomano, por exemplo, o autor deparou-se com uma paisagem exuberante, repleta de árvores frutíferas e riachos que permitiam o crescimento dos bosques sem intervenção humana. A sua admiração chegou ao ponto máximo quando ele avistara uma serpente voadora "com uma longa cauda e uma cabeça como a de um macaco, com uma boca grande e uma língua comprida; o corpo tinha cerca de quatro pés de comprimento". Ele adicionava a isso a afirmação de que os outros homens alegaram que nunca tinham visto nada parecido, o que fez T.S. propor que tal criatura não devia ser comumente encontrada na costa.

Além desse, houve outros momentos em que T.S. veria serpentes ou animais pouco comuns, e um acontecimento que ele mesmo chamaria de "muito extraordinário" ao final da narrativa. T.S. relatava que tinha visto "um estranho monstro nascido de uma mulher mourisca", com "a cabeça de um macaco, os pés de um ganso, o corpo de um homem, as mãos como as garras de um leão”. As pessoas na cidade ficariam terrificadas com o tal acidente, o que geraria a disseminação de "vários relatos". MacLean buscou interpretar esses episódios como uma indicação 
das diferenças entre os homens ingleses e as "bestas selvagens" que viviam nas terras da África, o que levaria ao desfile de preconceitos xenófobos nos séculos seguintes (2004, p. 204).

Para os interesses deste livro, o que tais episódios nos revelam é a possível transformação sofrida pela experiência de viagem e, particularmente, a mutação que afetaria as representações sobre o harém. Pela leitura da narrativa de T.S., verifica-se um amplo desinteresse em tratar as habitações femininas, fossem dentro do palácio, fossem nas casas comuns. Caso o seu relato tenha acentuado os episódios sexuais em detrimento de todos os outros ocorridos na viagem, a questão que se deverá levantar é: o fato de a viagem ter ocorrido no seio das sociedades islâmicas - nesse caso, no Norte da África - era uma premissa inquestionável para a sexualização do enredo do livro? Eis a pergunta que será considerada ao longo deste livro.

A escolha de viajantes com características distintas, as quais podem ser encontradas em um artesão, em um clérigo, em um advogado e em um comerciante, propiciou visões multifacetadas sobre o Levante, tornando-se, desse modo, de extremo valor para os objetivos aqui desenhados. A partir das variadas observações desses viajantes, foi possível vislumbrar um cenário mais complexo das relações entre a Inglaterra e o Império Otomano e entre aquele país europeu e o Norte da África, no caso de T.S. Dentro do que foi exposto, dois pontos merecem ser destacados. O primeiro diz respeito ao interesse dos ingleses pelas sociedades islâmicas ao longo do período moderno, o que levou Nabil Matar a defender as muitas possibilidades de negócios oferecidas pelo Mediterrâneo islâmico aos 
homens e às mulheres ingleses (VITKUS; MATAR, 2001, p. 1-52). Além disso, ficou evidente que o tema do harém não consistia em uma obviedade para estes viajantes.

Dito isso, é preciso ampliar a investigação sobre esse tema, buscando como fonte outro grupo de viajantes. Ou seja, cabe registrarmos o conjunto das representações sobre o harém e também sobre a sexualização das sociedades islâmicas dentre os viajantes franceses, investigando as similaridades ou as diferenças de imagens em relação aos autores ingleses. A comparação entre estes dois blocos de narrativas nos permitirá estabelecer balizas próprias ao texto e externas a ele - dados cruciais para seguirmos os rastros das representações europeias sobre o harém islâmico.

\subsubsection{Os viajantes franceses}

\section{"[...] Le XVIIe siècle prétend détruire les mythes médiévaux sur l'Islam au nom de la logique et de expérience vécue [...]". Dominique Carnoy (1998, p. 10).}

O interesse pelo Levante na sociedade francesa do século XVII era bastante evidente. A Pérsia, em particular, era não só muito visitada como admirada pelos franceses. Já o Império Otomano - dado o seu poder político - transformou-se em matéria de atenção para os franceses ao longo desse período. Os contatos entre os franceses e as sociedades asiáticas propiciaram uma "moda cultural pelo 'Orientalismo' na França” (HARVEY, 2012, p. 12). As experiências de viagem, assim como o aprendizado das línguas e das culturas islâmicas, podiam ser empregados 
na crítica política e social da própria sociedade francesa especialmente em relação à tese de "despotismo oriental" disseminada por Montesquieu ${ }^{29}$-, entretanto, havia autores efetivamente atraídos pelas particularidades do Levante. A extensão dos impérios islâmicos e o seu esplendor estavam entre os fatores que provocavam admiração nos viajantes (HARVEY, 2012, p. 13).

Assim como na Inglaterra, a literatura de viagem era também disseminada entre os franceses. Em termos numéricos, em oitenta anos - entre 1665 e 1745 -, “ao menos 150 relatos de viagem apareceram na França, uma porcentagem substancial de todos os livros publicados durante este período" (KUEHN; SMETHURST, 2009, p. 82). O já citado botânico e linguista Jean de Thévenot exprimiu com propriedade a disseminação das viagens na sociedade francesa do século XVII. Se o desejo de viajar sempre fora natural entre os homens - ele afirmava -, a paixão que os incitava a viajar nunca havia sido tão latente quanto naqueles dias. O volume de "belas viagens impressas" era prova disso (THÉVENOT, 1664, p. 1). Foram esses "belos relatos" inclusive que o levaram a pensar em viajar, o que ele fez extensamente em sua curta vida.

Os registros de viagem ao Levante produzidos ao longo do século XVII guardavam grandes diferenças em relação ao "discurso do Orientalismo clássico do século XVIII em diante" (HARRIGAN, 2008, p. 134). Além da latência do "perigo otomano" - ainda presente neste momento -, Michael Harrigan defende que a "suposta passividade do Oriente ‘moderno' que [Edward] Said descreve

${ }^{29}$ Ver o Capítulo 5 deste livro. 
é irreconhecível" nesses relatos (2008, p. 134). As narrativas de viagem alimentavam a curiosidade dos franceses pelas sociedades islâmicas e influenciavam a produção de vários textos ficcionais. Dentre os tópicos que mobilizavam a atenção dos franceses estava o serralho imperial. Sobre isso, o médico e viajante François Bernier (16251688), em viagem pelo Império Mogol, na Índia, lamentava o fato de não poder descrever melhor o serralho, afinal, o que ele poderia afirmar se havia visto tão pouco daquele lugar? (1671, p. 89).

Devido à recorrente apresentação do tema do serralho nos textos de viagem, é possível acreditar que tais narrativas foram se constituindo em uma importante fonte para a formação das representações sobre o harém. Como alega Harrigan, deve-se lembrar que ao longo do século XVII a narrativa de viagem adquiriu um "considerável nível de autoridade na representação cultural" (2008, p. 99). Isso significa afirmar que o conjunto discursivo formado por tais narrativas passava a ser visto como um corpus de informações que estava em constante expansão e que começava a exibir credibilidade na descrição das sociedades estrangeiras. Esta questão voltará a ser tratada no Capítulo 3.

Como já ocorrera entre os viajantes ingleses, o termo serralho aparecerá em muitos viajantes franceses como sinônimo de palácio imperial. É o que se pode verificar no texto do barão Henry [ou Henri] de Beauvau, que viajou ao Império Otomano com passagem por Jerusalém e pelo Cairo. A viagem iniciada em $1^{\circ}$ de novembro de 1604 estendeu-se até novembro de 1605. Embarcava com Beauvau o embaixador da França no Império Otomano, Jean de Goutaut-Biron, barão de Salignac. O livro, 
intitulado Relation iournalière du voyage du Levant, teve a sua primeira edição impressa na cidade de Toul, na França, em 1608, sendo impresso novamente em 1609, 1610, 1615 e em 1619 (POUILLON, 2008, p. 68).

Ainda que Beauvau não fosse um peregrino, mas diplomata, a sua narrativa possui um caráter marcadamente religioso. O livro foi dividido em seis capítulos, sendo a quarta parte inteiramente dedicada à cidade de Jerusalém. Ao longo de todo livro, as observações sobre o cristianismo com as suas igrejas e os seus lugares sagrados eram ressaltadas pelo viajante. A "Terra Santa" era motivo de especial desapontamento para o autor. Ele afirmava ao leitor: "Não é sem desagrado que eu coloco a mão sobre a pena para começar a descrição dos lugares santos, tanto da cidade de Jerusalém, como do entorno" (1608, p. 151). A explicação para isso vinha em seguida. Ele se recordava da rara devoção destes lugares, lembrando que tal região estava nas mãos dos infiéis. $\mathrm{O}$ autor assegurava que isso o deixara em tão grande melancolia, que ele perdera quase todo o desejo de escrever.

A religião, de fato, é o elemento que move o seu texto. Beauvau chegou a fazer um clamor aos príncipes cristãos para que se unissem em campanha pela conquista da "Terra Santa" (1608, p. 151-152). Concorrem com a descrição religiosa as anotações sobre a arquitetura das cidades, tema bastante explorado ao longo da obra. Sobre isso, o viajante afirmava que a cidade de "Constantinopla" era tão bela e agradável, que parecia ter sido feita para comandar o resto do mundo. Esta mesma ideia foi registrada por Henry Blount quando viajou para a cidade, em 1634 (1636, p. 25). 
Após focalizar a parte física da cidade, Beauvau dedicou-se, dentro da segunda parte da narrativa, a descrever a Corte do sultão otomano. O trecho do livro que faz a passagem das construções arquitetônicas para o interior do palácio mencionava, de partida, o conceito de serralho [serail]: o "lugar onde permanece" o soberano (1608, p. 55). Ao lado disso, o autor relatou os episódios que se estendiam desde a chegada do novo embaixador da França, Salignac, ao palácio otomano, até o momento em que eles se encontraram com o governante. Uma vez que o discurso do embaixador diante do vizir havia sido mediado por um intérprete, é certo que Beauvau também desconhecesse a língua asiática em questão (BEAUVAU, 1608, p. 43).

Dentro do serralho imperial, o autor fez notar a presença de trezentos e sessenta rapazes, entre dez e vinte anos, que eram dados ao soberano ou enviados a ele em troca de algum favor. Estes meninos não iam à guerra, mas permaneciam no palácio onde aprendiam a ler e a escrever (1608, p. 56). Em outra câmara - chamada por Beauvau de "Segunda Ordem" -, havia os rapazes que iam à guerra com o sultão e eram em maior quantidade (p. 57). Havia rapazes ainda na terceira câmara, na quarta câmara - onde ficavam noventa deles -, na quinta e na sexta câmaras. $\mathrm{Na}$ quinta câmara, havia cerca de quarenta jovens, todos eunucos ${ }^{30}$. Era aí que o rei tinha o costume de fazer as

30 Como lembra Cristina de La Puente, o termo eunuco originalmente remetia à função de guardador do quarto, e não de mutilado sexual. Em árabe, os dois termos para eunuco, jași e mayub, contudo, fazem alusão à mutilação (2003, p. 147). Quase todos os eunucos servindo no Império Otomano tinham tanto o pênis quanto os testículos removidos. Operações desta natureza levavam a um alto grau de mortalidade, além de "desordens hormonais e psicológicas”. Alguns eunucos ganhavam funções 
refeições e de ter os cabelos ou a barba cortados pelos jovens homens (p. 60). No sexto alojamento, ficavam trinta jovens em posse de armas e de cavalos (p. 64).

As mulheres, de outro modo, não aparecem como figuras de destaque na narrativa de Beauvau. A menção a elas é rara ao longo do texto. Em um desses momentos, o autor notava que no quarto das mulheres apenas o rei e o eunuco podiam entrar (BEAUVAU, 1608, p. 43). Não havia, além disso, qualquer curiosidade sobre as mulheres do soberano, como elas viviam, ou o que faziam dentro do palácio imperial. A "habitação feminina" não recebia, portanto, qualquer atenção especial. Para Beauvau, o serralho era a casa do rei onde entravam frequentemente pessoas ligadas à infantaria e à cavalaria. Ali, eram os homens os personagens realçados pelo viajante.

Ainda que Beauvau tenha ressaltado a presença de rapazes no palácio do sultão otomano, não havia em sua narrativa qualquer indicação sobre possíveis relações eróticas entre esses jovens homens e o governante. No seu relato, o serralho pode ser visto como um símbolo indesejado da presença muçulmana na cidade de Istambul, chamada por ele de Constantinopla. Sobre isso, o autor indicava que a igreja de Santa Sofia, construída pelo imperador Justiniano (c. 483-565), era a essa época muito maior, com uma abadia. A construção, entretanto, havia se estendido além do lugar original, abrindo espaço para o serralho. Na sua visão, isso indicava que os turcos, após se

de destaque no império (TOLEDANO, 1984, p. 382), mas não podiam acumular riqueza ou honra para os seus descendentes, caso existissem (MURRAY, 2000, p. 45). 
tornarem "senhores da cidade", tinham arruinado o que ali existia (BEAUVAU, 1608, p. 45). Fica evidente, portanto, que as preocupações de ordem política e religiosa se sobrepunham a outras matérias, incluindo-se a vida íntima do sultão e de suas mulheres.

O serralho, entendido como uma parte do palácio real que guardava o espaço privativo de convivência feminina, foi longamente citado e descrito no livro de Louis Deshayes de Courmenin (m. 1632), Voiage de Levant, fait par le Commandement du Roy en l'année 1621. O capítulo da narrativa dedicado ao tema do serralho e intitulado Descrição do Serralho do Grão-Senhor era resultado da viagem feita ao Império Otomano em 1621, com duração de onze meses, cuja impressão veio a público pela primeira vez em 1624.

Courmenin nasceu por volta de 1600 , e a sua origem remete à burguesia de Orleans. Como indica o próprio título da obra, Courmenin empreendeu a viagem a pedido do rei Luís XIII (1601-1643). Em função diplomática, a sua viagem para o Império Otomano tinha como objetivo fazer justiça aos franciscanos na "Terra Santa", cujos direitos estavam sendo lesados pelos religiosos armênios (PILLORGET, 1975, p. 66). O sucesso de sua obra contribuiu possivelmente para as outras viagens encomendadas pelo rei francês, de modo que ele seria enviado, já em 1624, à Dinamarca, com ambições político-diplomáticas (PILLORGET, 1975, p. 66).

No início de sua narrativa, Courmenin refletia sobre a maneira de escrever um relato de viagem. Ele reconhecia que o vocabulário usado era "muito simples e muito baixo" (1624, p. iii), o que remetia ao sentido de acessível. 
Mas isso não impedia, por suposto, que a obra se destinasse a um público de "cavalheiros" e "homens de letras". De todo modo, ainda que a função diplomática desta e das outras viagens empreendidas por ele fosse muito evidente, a sua narrativa não divergia do tom comumente empregado nos registros de viagem. A busca por descrever uma extensa variedade de assuntos, da arquitetura à política, abarcando as particularidades do palácio imperial, fazia-se também presente em sua obra. Não é possível saber, contudo, se Courmenin era um conhecedor de alguma língua asiática. De toda forma, a sua narrativa era construída a partir do que ele mesmo verificara dentro do palácio otomano (COURMENIN, 1624, p. 124). Além disso, em suas viagens, ele era acompanhado de um secretário que foi responsável inclusive pela publicação de sua obra (BRAINNE et al., 1852, p. 198). É possível que fosse este personagem o mediador de seu contato com os turcos.

Afora o destacado espaço dedicado ao serralho, o que chama a atenção nesta narrativa é o conjunto de modificações feitas a partir da segunda edição. Harrigan nota que as alterações em relação à edição de 1624 podem ser encontradas já em 1629. A fim de verificar tais mudanças no relato de Courmenin, usarei aqui as publicações de 1624 e de 1629 , além da edição de 1645 . A comparação entre elas nos ajudará a dimensionar o espaço dedicado ao tema do serralho e a importância atribuída a este tópico ao longo desses vinte e um anos.

Os oito títulos usados na primeira edição foram mantidos nas publicações de 1629 e de 1645 . O subitem Departamento das mulheres, inserido no capítulo Descrição do Serralho do Grão-Senhor, recebeu, contudo, uma 
ampliação. Se em 1624 havia cinco páginas destinadas a este assunto, a partir de 1629 - e também em 1645 - já eram dez páginas. A própria palavra "mulheres" desta subdivisão passaria a ser grafada com letra maiúscula. Tal alteração poderia ser uma mera opção tipográfica ou, de outro modo, ser uma forma de conferir destaque a esta palavra. O outro subtítulo deste capítulo - Os Jardins do Serralho - também seria aumentado em duas páginas ${ }^{31}$.

O capítulo se inicia do mesmo modo nas três edições, com a definição do termo serralho. $\mathrm{O}$ autor notava que serralho - "Seray, em língua persa" - era o significado para "palácio", além de ser o nome dado a todas as casas do Grão-Senhor e de seus principais oficiais. Enquanto na primeira edição o autor adotava um tom impessoal, afirmando que havia vários serralhos no Império Otomano, a partir da segunda edição a indicação era personalizada, apontando-se que o príncipe possuía várias residências. Ainda que o viajante afirmasse sobre a profusão de tais construções por Istambul e em lugares distantes, a descrição feita se referia apenas ao serralho da capital otomana.

Uma primeira modificação em relação à publicação original já poderia ser notada no segundo parágrafo deste capítulo. No lugar de "aquele [serralho] de Constantinopla" da primeira edição, anotava-se "O serralho de Constantinopla” (COURMENIN, 1629/1645, p. 127). Alterações em relação aos parágrafos também foram feitas, como aquela que subtraiu uma informação sobre as

${ }^{31} \mathrm{Na}$ edição de 1624, o capítulo Description du Serrail du Grand Seigneur corresponde às páginas 122-163 e Departement des femmes, às páginas 145-150. Nas edições de 1629 e de 1645, a paginação é a mesma: 127-182 para o capítulo inteiro, e 157-167 para o tema das mulheres no serralho. 
construções arquitetônicas, na primeira edição, abrindo espaço ao tema do serralho, na segunda edição. Houve ainda a substituição de "príncipe" por "grande Senhor" (1629/1645, p. 145).

A partir do confronto de tais edições, é possível afirmar que o viajante intensificou as referências acerca das riquezas e do luxo do serralho. Se na primeira edição Courmenin observava que o governante usava geralmente o lavabo feminino, nas edições seguintes verificava-se a anotação de que os banheiros femininos eram "ainda mais ricos e mais belos" (1629/1645, p. 154). Essa atenção voltada ao luxo do serralho otomano pode ser pensada a partir da expansão do comércio no Mar Mediterrâneo e do acesso restrito dos europeus - ainda ao longo dos séculos XVI e XVII - a uma série de produtos (PERROT, 1995, p. 17).

Mais do que isso. Se considerarmos a afirmação de Jean Paul Sartre de que o luxo não designa tanto a qualidade do objeto possuído, mas "a qualidade da posse" (PERROT, 1995, p. 19), é possível pensar que a admiração em torno do luxo do palácio otomano ocorresse, em grande medida, pelo poder político-econômico exibido por este império. Isso se torna ainda mais plausível se considerarmos que neste momento a Europa atravessava turbulências políticas, religiosas, sociais (MUNCK, 1989). Esse gosto pelo Levante, que se manifestava, sobretudo, nos elementos tomados da literatura, da moda, dos costumes, tornou-se mais intenso no século XVIII. Tal “moda orientalista" passaria à literatura sob o nome de turqueria (MEYER, 1974). 
As indicações sobre o luxo dividiam espaço com as observações sobre o caráter de reclusão a que estavam submetidos os personagens que viviam no serralho. Em um trecho que não consta da primeira edição, o autor ressaltava o isolamento do serralho em relação ao restante da cidade:

O serralho é como uma República, separada do resto da cidade, com as suas leis e o seu modo de vida particular; as ordens são facilmente conservadas, porque aqueles que aí vivem não têm outros conhecimentos do que aquilo que eles aprenderam e nem de outras luzes, além daquelas que receberam: eles não sabem o que é liberdade (COURMENIN, 1629/1645, p. 155).

O serralho, que mantinha a preservação de suas práticas impossibilitando que fossem reconhecidas pelo restante da população, era o mesmo que acolhia integralmente o Grão-Senhor. Este delegava os assuntos de Estado mais importantes ao seu vizir e passava a vida em um "contínuo isolamento, com as crianças, as mulheres, os eunucos, os mudos e com os anões, que lhe reverenciam como um Deus e tremem somente ao verem a sua sombra" (1624, p. 137, $1629 / 1645$, p. 156). Faz-se necessário notar que este trecho, alocado no meio do texto da primeira edição, foi deslocado para o último parágrafo das duas edições seguintes, o que poderia lhe conferir mais destaque.

A maior surpresa da obra ficaria por conta do último subitem do capítulo, o "Departamento das mulheres". A partir da segunda edição, o autor trazia à tona fatores de ordem religiosa que não haviam sido mencionados na edição de 1624. Então, Courmenin deixaria logo assinalado 
que as mulheres no serralho eram "renovadas de tempos em tempos, à medida que se empreendem guerras contra os cristãos" (1629, p. 157). Ato contínuo, o viajante afirmava que a primeira prática imposta às mulheres levadas ao serralho era a mudança de religião, o que seria feito através da pronunciação indicando que não havia outro Deus, senão Deus, e que Muḥammad era o seu profeta (p. 157-158).

O destaque desta seção, contudo, concentrava-se mesmo nos aspectos que caracterizavam a particularidade do serralho. O número de mulheres que habitavam este espaço (oscilando em torno de trezentas), a relação entre as mulheres, a função dos eunucos, os problemas jurídicos acerca dos filhos nascidos de odaliscas (escravas) e de esposas legítimas eram os temas tratados, de modo que as pistas que nos dá Courmenin podem nos levar a traçar um perfil geral sobre as mulheres que viviam no harém. Sobre o número de mulheres no serralho, especialmente, há que se lembrar da mudança no sentido dos termos. Isto é, enquanto na primeira edição Courmenin afirmava que o número de mulheres poderia passar de trezentas, na segunda e terceira edições, lia-se que "elas são mais de trezentas" (1629/1645, p. 160).

O retrato das mulheres que viviam no serralho otomano era feito a partir de uma ótica generalizante, ou seja, o viajante não personalizou qualquer uma delas mencionando alguns de seus nomes, por exemplo. Além disso, informações importantes desse cenário foram subtraídas, de modo que a leitura isolada da primeira edição ou da segunda levaria a conclusões distintas sobre esse espaço. Foi retirada do texto de 1629 a notícia de que as 
sultanas e aquelas mulheres que o Grão-Senhor apreciava eram "mais bem tratadas" e "bebem sorbets" excelentes que são importados do Cairo" (COURMENIN, 1624, p. 148). No lugar deste trecho, era inserida a informação de que as mulheres desempenhavam a função de matronas ou prestavam serviços para os mais jovens quando elas não podiam mais dar satisfação ao príncipe (COURMENIN, 1629/1645, p. 160).

Um dos temas alongados na segunda edição da obra se referia aos casamentos entre o governante e as mulheres no harém. Como pontuava Courmenin, os príncipes otomanos esposavam as mulheres à custa de grandes despesas nas cerimônias. Tais gastos, somados ao dote dado às esposas, eram uma "espécie de sujeição" para o homem, avaliava o viajante (COURMENIN, 1629/1645, p. 162). Não é raro constatar que este tipo de posicionamento gerava a crença entre os europeus de que as "mulheres do harém" exerciam maléfica interferência sobre o sultão e, por conseguinte, sobre a política otomana. Este tema será retomado no último capítulo deste livro.

Logo na sequência, Courmenin tocava em outro tema sensível quando se tratava do harém imperial: a liberdade feminina. $\mathrm{O}$ autor reconhecia que nenhuma destas mulheres jamais saía do serralho, a menos que o Grão-Senhor as levasse consigo. Contudo, ele defendia que, à exceção da liberdade, elas não teriam nada a desejar neste recinto, "fosse pela beleza dos jardins repletos de fontes, e de outros

32 O sharbat em árabe ou şerbet em turco é uma bebida feita à base de xarope de frutas ou extrato de flores, misturado com gelo (KITTLER; SUCHER; NELMS, 2012, p. 409). 
enfeites rústicos, fosse pelas habitações que são muito ricamente mobiliadas" (p. 164-165). Courmenin lembrava ainda que a guarda dessas mulheres era feita por eunucos que se pareciam mais com monstros do que com homens, o que as levaria a crer na maior beleza do Grão-Senhor (COURMENIN, 1624, p. 145-146, 1629/1645, p. 165).

O que as alterações na segunda edição nos mostram é que, mesmo havendo razões objetivas para que o texto fosse modificado, o autor não conseguiu omitir as contradições que formavam o serralho imperial. Ou seja, as mulheres que compunham esse espaço eram de lugares e de culturas variadas, e, dentro do palácio, eram tratadas de formas diferentes. A hierarquia era um instrumento utilizado, e, além das funções ocupadas por essas mulheres, as relações estabelecidas entre elas e os funcionários, entre elas e o governante, e entre elas mesmas, revelavam a impossibilidade de se projetar a imagem de uma mesma mulher, repetida várias vezes.

A presença de jovens rapazes no serralho otomano também era mencionada por Courmenin, mas diferentemente dos viajantes que citavam as relações eróticas estabelecidas entre eles e o sultão, o diplomata francês não fazia referência a tal matéria. O autor apontava - já na primeira edição - que os rapazes capturados pelos turcos, em suas conquistas militares, eram "muito belos". O viajante, entretanto, não fazia qualquer sugestão sexual sobre a escolha dos turcos por garotos bonitos.

Courmenin é o primeiro viajante citado até o momento que fez menção à vida luxuriosa na Corte Otomana, considerando para tanto as relações entre o sultão e as suas mulheres. Em um trecho adicionado à segunda 
edição, ao final do item "Departamento das mulheres", o autor exibia a sua visão deleitante sobre o harém. Agradáveis e amorosas, as mulheres propiciavam divertimentos ao corpo e à mente do soberano. É certo que o viajante relacionava tamanha afabilidade à esperteza dessas mulheres, que utilizavam a dissimulação para evitarem quaisquer castigos. Ainda que fosse assim, o sultão se entregava "facilmente a este tipo de prazer, levando uma vida muito lasciva e muito deliciosa" (COURMENIN, 1629/1645, p. 167).

Três anos após a viagem de Courmenin, ou seja, em 1624, era publicada a narrativa de Michel Baudier (c. 1589-1645), Histoire generalle du serrail et de la cour du Grand Seigneur Empereur des Turcs. Uma vez que não foi possível consultar a primeira publicação, utilizarei aqui a segunda edição desta narrativa, impressa em 1631. Baudier, que havia feito carreira militar, interessava-se pela história e produziu ao todo onze obras. O seu conhecimento acerca de diversas línguas, como latim, grego, árabe, hebraico, italiano e espanhol, contribuiu certamente para a extensão de seus escritos (POUILLON, 2008, p. 62). Seus temas se concentravam na história da França e da Europa, mas também do Império Otomano, da China e da Pérsia. Como um escritor de talento destacado e de grande erudição, Baudier conquistaria o título de historiador na Corte de Luís XIII.

O caso de Baudier guarda uma particularidade em relação aos outros autores. Levantou-se a suspeita de que ele não teria viajado ao Levante (IORGA, 1928 apud POUILLON, 2008, p. 62). Logo, o seu texto não seria uma narrativa de viagem. Diante disso, faz-se necessária uma justificativa para a inserção de sua obra em meio aos 
viajantes franceses. Baudier utilizou-se, sobremaneira, de fontes de viagem para compor os seus textos. No caso da Histoire generalle du serrail - livro que foi reeditado várias vezes ao longo do século XVII, sendo traduzido para o inglês, como citado antes -, Baudier "recorre a numerosos relatos sobre o serralho que circulavam então na Europa e que exibiam um forte interesse" (POUILLON, 2008, p. 62).

A obra de Baudier sinalizava, ao menos na teoria, que a sua elaboração se dera tanto por meio de outras fontes textuais quanto a partir de sua própria experiência, de modo que podemos encontrar a menção aos "verdadeiros exemplos que as histórias fornecem" e, na mesma medida, a necessidade que ele teve em "ver de muito perto os Reis", aproximando-se do "mais soberbo de todos os Príncipes". Isso foi essencial para que ele pudesse pesquisar e descrever os elementos secretos da Corte Otomana (BAUDIER, 1631, p. 1). Assim, após escrever uma história sobre o Império Otomano, Baudier alegava não parecer inútil discorrer sobre os costumes, os modos de vida, a forma de governar dos turcos. Para tanto, justificava o autor, era preciso entrar no serralho, "onde o segredo de todas as coisas é cuidadosamente guardado" (p. 2).

A História geral do serralho está dividida em duas partes, sendo a primeira composta por dezenove capítulos, e a segunda, por vinte capítulos. Houve um esforço de Baudier por sistematizar o funcionamento do serralho real - entendido aqui como sinônimo de palácio -, descrevendo as vestimentas, a alimentação, a atuação médica, a educação das crianças que ali viviam, assim como os amores do Grão-Senhor e de suas mulheres. Contudo, 
diferentemente dos outros viajantes-autores, Baudier não fez menção ao suposto dia de sua partida, nem em que dia ou mês teria chegado ao Império Otomano, o que pode aumentar as suspeitas sobre a veracidade de uma experiência empírica.

Antes de iniciar o capítulo II, intitulado Do Serralho do Grão-Senhor, Baudier tecia um comentário que reforçava o grau de cuidado com que o serralho era guardado, convidando o leitor, ademais, a conhecer as "raras belezas deste augusto lugar" (1631, p. 17). O autor afirmava sobre a existência de três serralhos - ou palácios - em Istambul, visto que o "Grande serralho" havia sido construído sobre o local em que estava situada a antiga cidade de Bizâncio. Esta informação, quase nos mesmos termos, aparecerá na segunda edição do texto de Louis Deshayes de Courmenin, quando ele escrevia que "o Serralho de Constantinopla está construído [...] no mesmo lugar onde foi primeiramente edificada Bizâncio” (1629/1645, p. 127). Além disso, a definição de serralho dada por Baudier e por Courmenin era a mesma, qual seja, a de que "saray", em persa, significava palácio (BAUDIER, 1631, p. 47). Ao lado disso, era possível notar a recorrência da beleza do serralho que aparecia atrelado a construções de mármore e a belos jardins e fontes.

Já no capítulo II, Baudier definia o espaço dedicado ao convívio feminino dentro do palácio. Contava ele que "o departamento onde estão alojadas as mulheres e jovens moças devotadas ao prazer do Imperador é como um grande Monastério de Religiosos: mas que não guarda o voto de castidade [...]” (1631, p. 19). À exceção de uma possível ironia do comentário, o que se lia em seguida era 
um conjunto de elementos que aparecia, em maior ou em menor medida, em outros viajantes. É o caso, por exemplo, da habitação feminina protegida por uma tropa de "eunucos negros e medonhos" (p. 22).

$\mathrm{Na}$ narrativa de Baudier, nota-se, pela primeira vez e de forma deliberada, a influência da paixão das sultanas sobre o soberano otomano. $\mathrm{O}$ autor descrevia como se organizava a noite de núpcias do governante, acentuando os presentes recebidos pela nova esposa. Vestidos feitos de ouro, pedrarias, prata estavam entre as ofertas do sultão. A quantidade de presentes era proporcional aos prazeres recebidos pelo soberano na noite anterior. Assim, para viver este amor, o soberano perdia um pouco de suas riquezas, dizia o autor. Para Baudier, o amor se definia como "uma agradável ferida, um doce amargor, um veneno saboroso, uma doença que lhe agrada, uma tortura que eles abraçam e uma morte para a qual eles correm" (1631, p. 49). Esta era uma descrição típica do amor-doença, assim entendido pelo cristianismo e mesmo por certos representantes da medicina europeia (CARNEIRO, 2000, p. 35-54).

No capítulo XI, intitulado As mulheres do Grão-senhor, a sua habitação, a sua vida, a sua conduta e a sua fortuna, o autor buscou destacar os amores das mulheres do serralho. Baudier lembrava que tais mulheres eram "normalmente estrangeiras, cativas de guerra ou levadas à força” para o palácio (1631, p. 54). Havia em torno de trezentas dessas moças no palácio. Não é demais lembrar que Courmenin havia citado esse mesmo número na sua obra. Curiosamente, entretanto, os rapazes eram ali mais numerosos do que as mulheres: eram quinhentos, afirmava Baudier, variando entre doze e trinta anos de idade (p. 57-58). 
Dentro do palácio, as moças aprendiam regras de "civilidade", tocavam instrumentos musicais, cantavam e faziam trabalhos de costura (BAUDIER, 1631, p. 54). Aqui também é possível perceber o incômodo de Baudier em relação à religião islâmica, afinal, ele destacava o fato de que essas mulheres, que eram cristãs, deviam servir aos "desonestos prazeres dos Turcos", o que ele enxergava como um desastre. O autor observava, ademais, que ao chegarem ao palácio essas moças deveriam fazer a profissão de fé islâmica, informação que também será realçada por Louis Deshayes de Courmenin na segunda edição de sua obra.

De acordo com a descrição de Baudier, as mulheres recebiam diversos presentes em reconhecimento da "fidelidade e da diligência de seus serviços" (1631, p. 58). Os presentes normalmente se traduziam em joias ou em outros ornamentos enfeitados de ouro, ou ainda em móveis. Mas o que elas mais gostavam de acumular era prata. A beleza de tais mulheres não impedia, de outro modo, que elas demonstrassem os "defeitos de seu sexo, que está sujeito à avareza". O autor não deixava de indicar a fonte de sua tese: tratava-se da "Retórica" do pensador romano Cícero (106 a.C.-43 a.C.), cuja frase anunciava "mulierum genus est avarum", ou seja, o gênero feminino é avarento (p. 58).

Além da avareza, o autor acentuava outras características não virtuosas dessas mulheres. Baudier assinalava que muitas delas iam ao quarto da mãe do governante a fim de se destacarem aos olhos do imperador. A beleza e os encantos que tais moças exibiam eram tomados como perigosos pelo autor, e a explicação sobre esse tema se 
revelava novamente em uma frase em latim: o efeito de uma mulher má sobre os homens era o naufrágio destes (BAUDIER, 1631, p. 55). O comportamento feminino era visto, portanto, como uma "experiência infeliz", uma vez que tais mulheres se utilizavam de malícia e de dissimulação. A mulher era o "naufrágio do homem", mas como encerrava o autor, era "um mal necessário" (p. 55-56). Neste capítulo, Baudier tecia considerações sobre a complicada relação entre as mulheres e o soberano. Caso uma mulher do serralho traísse o monarca em um caso amoroso, a lei turca estabelecia sua morte, sem possibilidade de perdão. A moça seria, então, colocada em um saco e jogada ao mar. Para "faltas menores", elas poderiam apanhar ou ser levadas ao "Velho Serralho", construído após a conquista de Constantinopla (p. 62). A "mulher viciosa", como o autor nomeava, era, além disso, "muito industriosa", pois buscava satisfazer os seus desejos ainda que estivesse fechada no harém e fosse vigiada por eunucos.

Pautando-se no poeta romano Ovídio (43 a.C-18 d.C), Baudier afirmava que a beleza era um "bem frágil", sendo deteriorada seguramente pelas doenças. Se a mulher doente não fosse a preferida do soberano, as mulheres mais velhas, que governavam as outras, se reportavam ao boticário "fora da porta interior do Serralho", mostrando a ele a urina daquela que padecia. Sem ver a paciente, o médico receitava a ela algum procedimento para aliviar o sofrimento. Muitas, contudo, morriam por não serem atendidas a contento.

Se a mulher doente fosse a sultana ou alguém que o soberano estimasse muito, o médico seria chamado a fim de examiná-la. Nesse caso, o médico seria levado pelos 
eunucos até à paciente, que estaria com o rosto coberto, e teria apenas o braço - também coberto por um tecido tomado pelo médico. O pulso seria verificado e durante todo o procedimento o médico não tinha permissão para falar com a mulher doente. Algum medicamento era prescrito, mas como ressaltava o autor, a medicina era "muito negligenciada nesta Corte". Isso se devia ao fato de os turcos acreditarem que no dia de seu nascimento a duração do seu tempo de vida era gravada em sua fronte. Dessa maneira, o destino não poderia ser alterado por qualquer tipo de medicamento (BAUDIER, 1631, p. 63).

Não foi tanto a paixão do sultão por mulheres que impressionara Baudier. $\mathrm{O}$ autor se mostrou mais impactado com a "paixão não natural" do soberano por homens e por jovens rapazes. $\mathrm{O}$ autor afirmava que no Levante esses moços eram vistos como a "flor da Beleza" e os "atrativos da Graça”, sendo, por conseguinte, condenados à “infâmia destes abomináveis prazeres” (BAUDIER, 1631, p. 53). Para ele, tal “desordem é tão inveterada no serralho", que dos vinte imperadores otomanos que haviam ascendido ao poder até aquele momento apenas dois eram "puros deste vício" (p. 53).

O soberano não era o único inclinado a tais desejos. Em um capítulo sobre os baxás e outros homens com destacadas funções no império, o assunto voltou à tona. Baudier assegurava que esses homens "deixam frequentemente os amores das mulheres, dedicam as suas afeições aos jovens rapazes e seguem loucamente os encantos de sua suave beleza; eles os estimam e se servem deles no lugar das mulheres" (1631, p. 155). O autor afirmava que este "vício abominável" era corrente na Corte Otomana, 
de modo que os homens comentavam abertamente sobre os belos jovens trazidos de países estrangeiros e que dominavam os seus pensamentos e desejos. Isso levou Baudier a se perguntar: "que virtude, que sabedoria, que piedade se pode encontrar em uma Corte composta de tais homens?" (p. 156).

Esse "vício" era comparado ainda a uma doença. Como exclamava o autor, "o príncipe é o médico do Estado", mas, de que forma o soberano poderia combatê-la se ele mesmo se encontrava doente? (BAUDIER, 1631, p. 53). Diante disso, Baudier alertava que "todo o príncipe que ama o seu trono, o seu cetro, o seu Estado, deve fugir do vício e estimar a sabedoria" (p. 54). Fazendo isso, ele poderia se tornar a segurança do seu reino e o apoio para o seu povo (p. 54). A julgar pela recorrência de afirmações sobre a homossexualidade otomana, pode-se acreditar que já nesta época a imagem circulasse significativamente entre os europeus.

Uma das possíveis razões a reforçar tal imagem pode ser buscada no frequente deslocamento de jovens rapazes - fossem como espólio de guerra, fossem comprados - ao Império Otomano. Essa prática, mencionada por Henry Blount e por Henry de Beauvau, revelava que a função de tais rapazes não se restringia apenas ao cenário político-diplomático otomano, no desempenho da função de janízaro, por exemplo. Para os europeus, a presença desses jovens na Corte assinalava, além disso, a existência de relações homoeróticas entre tais rapazes e as figuras políticas deste império, incluindo-se o próprio sultão (MURRAY, 2000, p. 55). 
Peças para compor esse cenário lúbrico não faltavam. E aqui o testemunho dos viajantes é mais uma vez exemplar. Já havia menções às relações homoeróticas entre os turcos e os seus jovens escravos desde, ao menos, o fim do século XV. A esse respeito, Lybyer, escrevendo em 1913, citava o viajante genovês Jacopo de Promontorio de Campis. O viajante atribuía, por volta de 1475 , a baixa natalidade turca - especialmente na Anatólia e nas regiões do antigo Império Bizantino [nomeada pelos turcos de Romélia] - à "infinita luxúria de vários escravos e de jovens rapazes para quem eles se entregam" (apud MURRAY, 2000 , p. 56). O tema também estava presente na obra de Paul Rycaut [ou Ricaut] (1628-1700), acadêmico do Trinity College, que se tornou secretário do embaixador inglês em Istambul em 1661. Dentre as suas anotações, figurava a paixão entre os jovens rapazes, e entre eles e personagens de eminente destaque no serralho (RYCAUT 1668 apud MURRAY, 2000, p. 55).

O tema das relações homoeróticas não se restringia certamente aos homens. Baudier conduzia o seu texto de modo a explicar as consequências deste mau comportamento masculino. O capítulo XV, intitulado Dos amores das grandes Damas da Corte Turca e das ardentes afeições entre elas, listava as razões que levavam as mulheres a manterem relações com mulheres e também com outros homens. Baudier era contundente: "os ardores de um clima quente, a servidão das mulheres fechadas [no palácio], e o mau exemplo dos maridos lúbricos, são os principais motivos dos amores aos quais as Damas Turcas se entregam” (1631, p. 157). 
Nesse item, Baudier mostrava tanto a sua reprovação diante dos amores das mulheres turcas por homens estrangeiros quanto por outras mulheres. $\mathrm{O}$ que levaria uma mulher do palácio a manter relações amorosas com os franceses? O autor respondia que isso podia ser explicado pela "gentileza de seu humor, a graça de seus corpos [afirmavam elas] e as comuns cortesias de sua nação" (BAUDIER, 1631, p. 158). Ele alertava, contudo, que essas relações poderiam trazer graves consequências, afinal, após passarem alguns dias com os seus amantes, essas "mulheres cruéis" os envenenavam ou esfaqueavam, e se livravam de seus corpos em algum lugar escondido.

Não eram apenas os homens estrangeiros que despertavam as paixões nessas mulheres. É comum, nos dizia Baudier, que elas se tornassem apaixonadas por outras mulheres. Isso ocorria principalmente com aquelas que ficavam fechadas no serralho ${ }^{33}$. Baudier nomeou tais paixões de "amores ilegítimos". Mais uma vez, o autor mostrava uma possível razão para essa "desordem": a vingança das mulheres diante dos "amores não naturais de seus maridos". Ele afirmava, ainda, que no Levante "a maior parte dos homens" e os grandes nomes do império "se perdem nesta obscenidade e violenta luxúria” (BAUDIER, 1631, p. 159). Baudier descrevia o amor entre as mulheres como um sentimento associado à loucura, a algo doentio, de modo que ele se guardava o direito de não detalhar os atos entre elas, por uma questão de pudor.

$\mathrm{O}$ autor, porém, não abandonaria completamente o assunto, uma vez que continuava a retratar os amores

\footnotetext{
33 É importante considerar que a reclusão ao harém poderia ser uma razão mais "presumida do que observada", como escreve Murray (1997, p. 97).
} 
femininos. A própria sensualização que ele não queria ressaltar transpareceu na sua narrativa, afinal, ele mencionou tanto os encontros promovidos no banho - mais um alegado motor das relações eróticas entre mulheres -, e os beijos entre corpos nus, alegando que tais encontros eram frequentes no Levante. Baudier concluía com a seguinte afirmação: "assim vivem os povos distantes da luz da verdadeira fé, nas trevas da ignorância maometana", exibindo o "excesso de toda sorte de vícios" (1631, p. 160).

Ao final de seu livro, Baudier assinalou, uma última vez, a frouxidão de costumes dentro do palácio imperial. Os sultões otomanos passavam os dias à sombra de seu serralho, em meio aos prazeres com as suas sultanas. $\mathrm{Ou}$ seja, "a moleza de seus exercícios deprecia a sua glória, entorpece os seus espíritos [sic], corrompe os humores de seu corpo e diminui a sua vida: porque as delícias matam mais homens do que a espada" (BAUDIER, 1631, p. 180). Antes disso, logo no Prefácio, o autor francês já havia chamado a atenção para as três paixões que dominavam aqueles pouco virtuosos: o amor, a crueldade e a avareza. Não sem motivo, o autor chegava ao termo de seu texto ressaltando uma tese que figurava logo no início do livro. O capítulo final tratava da morte e do funeral do soberano otomano. Para o autor francês, os governantes desse império, não virtuosos em sua grande maioria e afeitos a ideias pouco iluminadas - mas que haviam sido outrora o "terror dos homens" e o "flagelo de muitas nações" -, tornavam-se "objeto dos vermes e a sua ordinária pastagem", terminando aí para eles a glória deste mundo (p. 183).

Diferentemente de Michel Baudier e da maior parte dos outros viajantes citados até o momento, o nosso 
último viajante do século XVII não rumou em direção ao Império Otomano. Empreendidas na segunda metade do século, as viagens do joalheiro protestante Jean Chardin (1643-1713) ao Império Persa mereceriam uma análise detalhada, afinal, a sua experiência de duas viagens ao Levante, assim como a extensa obra resultante dela, tiveram uma influência visível sobre outros viajantes e pensadores do século XVIII. A sua primeira viagem à Pérsia data de 1665. Ele chegou a este império no início de 1666 - fez uma rápida incursão pelas Índias - e voltou à Pérsia, onde permaneceu durante este ano e boa parte do ano seguinte, regressando à Europa em 1670.

A "paixão" que o viajante teve em conhecer bem este império - o que lhe rendeu a possibilidade de "dar boas e amplas informações” - fez com que ele retornasse. Então, em 1671, Chardin iniciou a sua segunda viagem à Pérsia, entre outras razões, para escapar das dificuldades vividas pelos protestantes em Paris (POUILLON, 2008, p. 195). Há que se ressaltar que a sua viagem pela Pérsia tornou-se possível, em grande medida, em virtude do auxílio de missionários teatinos e capuchinhos (AMES; LOVE, 2003, p. 57 $)^{34}$. Em sua segunda viagem, que se estendeu até 1677, Chardin afirmava que havia se interessado pelo estudo de línguas, assim como pelas conversas com sábios, o que o levou a se instruir em tudo o que merecesse a

34 Os missionários destas ordens cristãs haviam estabelecido uma série de postos através das rotas de comércio terrestres e marítimas. Foi a eles que Chardin recorreu em momentos de perigo, como no episódio envolvendo a suposta intenção do príncipe de Cólquida [região a leste do Mar Negro] em tomar o viajante como escravo branco, ou mesmo na tentativa de assaltá-lo. Os capuchinhos foram essenciais, além disso, para que Chardin conseguisse entrar nas Cortes oficiais em Isfahan (AMES; LOVE, 2003, p. 57). 
curiosidade da Europa em relação a um país que "nós podemos chamar de outro mundo, seja pela distância dos lugares, seja pela diferença dos costumes e das máximas" (1686, tomo 1, p. xii).

O seu interesse pela Pérsia levou-o a aprender a língua turca e persa, "mais do que qualquer um que escreveu sobre a Pérsia" (1686, tomo 1, p. xi). De acordo com Lucette Valensi, Jean Chardin também sabia árabe (apud POUILLON, 2008, p. 195). O viajante dedicou tanto empenho em se instruir sobre a Pérsia, que ele afirmaria conhecer melhor Isfahan do que Paris, que era o lugar onde nascera e havia sido criado. Esses princípios impediam que o viajante escrevesse sobre as Índias, pois ele não estava familiarizado com a língua dos Brâmanes, e sem este instrumento - completava -, não se poderia chegar a conhecer a sabedoria e a antiguidade dos indianos (CHARDIN, 1686, tomo 1, p. xiv-xv).

Os livros resultantes das viagens foram por ele divididos em dez volumes. O primeiro deles foi publicado - simultaneamente na França e na Inglaterra - em 1686 (AMES; LOVE, 2003, p. 51). No caso da Inglaterra, a narrativa foi impressa em francês e também recebeu tradução para o inglês. O último volume da obra seria publicado em 1711. Uma edição acrescida de notas e de um texto sucinto sobre a História da Pérsia seria ainda publicada pela editora Le Normant em 1811. Nesta edição, a obra manteve o mesmo número de volumes do texto original. Este mesmo formato foi adotado pela edição mais recente da narrativa de Chardin (2001).

As viagens de Chardin foram estimuladas primeiramente pela venda de joias e também pela compra de pedras 
preciosas (POUILLON, 2008, p. 195). Por tal motivo, ele seria nomeado o negociante do xá Abbas II (m. 1666). Mas não foram somente os assuntos de ordem comercial que povoaram as páginas da sua extensa obra. O palácio do soberano persa também figurou entre os interesses do viajante francês, uma vez que as referências sobre o harém e sobre os personagens que o habitavam seriam abundantes.

A caracterização luxuriosa desse império se revelava logo no primeiro volume da obra. Ao passar pela Geórgia, que estava sob domínio do Império Persa, Chardin discorreu sobre os vícios deste povo. Embora o autor declarasse a sua simpatia pelos georgianos, ele afirmava sobre os seus muitos vícios. Dentre estes, estavam a sua sensualidade muito impura (CHARDIN, 1686, tomo 1, p. 239), a embriaguez e a luxúria. As mulheres também eram retratadas como viciosas e desagradáveis. Chardin defendia inclusive que elas possuíam mais responsabilidade do que os homens no tocante à impureza que "inunda todo o seu país" (p. 240). Em outra região de domínio persa, a Mingrélia [Samegrelo, na atual Geórgia], Chardin declarava que "a concubinagem, o adultério, a bigamia, o incesto e vícios similares" eram virtudes (p. 108).

Ao lado dessas observações, o viajante destacava a suntuosidade da Pérsia, afirmando que não havia país onde o luxo e o esplendor fossem maiores. Esta característica, entretanto, não era propriamente um elogio, pois, para Chardin, tanto luxo seria a causa da ruína dos persas (1686, tomo 4, p. 159). Além do luxo, outro fator responsável por tal ruína era a política deste "governo arbitrário". Aqui, a Pérsia dividia a alcunha com os Impérios Otomano e Mogol. A política nefasta destes países fazia com que a 
sua população diminuísse e exaurisse as riquezas também. O despovoamento da Pérsia se devia, ainda, entre outras razões, à "luxúria imoderada do país" (CHARDIN, 1686, tomo 4, p. 12).

As indicações sobre o serralho podem ser encontradas de maneira pulverizada ao longo de todos os volumes de sua narrativa. No item Femmes (mulheres) do índice geral da obra publicado no décimo volume - que se referia à segunda viagem de Chardin para a Pérsia -, o viajante ressaltava como as mulheres persas eram intensamente guardadas ali mais do que em qualquer outro lugar do mundo. Em um pequeno texto ao final do terceiro tomo, em formato de nota de rodapé, Chardin escreveu ainda que "o apartamento das mulheres na Pérsia se chama Harém, ou seja, um lugar sagrado, cuja entrada é interdita e protegida" (1686, tomo 3, p. 209).

Dentre os viajantes estudados até o momento, Chardin foi o primeiro a empregar a palavra harém como sinônimo de serralho. Eis a definição dada para este espaço: "é a parte do Palácio Real onde permanecem as mulheres, que os turcos chamam Serralho, e para a qual o acesso é interdito a qualquer homem que não seja o soberano" (1686, tomo 3, p. 171-172). Em seguida, Chardin observou que havia três portas até se alcançar este lugar. Pela primeira, as pessoas passavam livremente. A segunda porta era aberta somente aos oficiais da casa do governante ou àqueles que possuíam uma ordem expressa. $\mathrm{E}$, finalmente, a terceira porta era guardada pelos eunucos, e a ela não era permitido qualquer olhar (p. 172).

A partir do quinto tomo da obra, havia uma descrição mais extensa sobre o harém. No tomo sexto, havia 
inclusive um capítulo dedicado ao tema, intitulado "O Palácio das Mulheres do Rei”. Chardin indicava que havia um primeiro grupo, de eunucos brancos, que guardava as mulheres. Logo em seguida, ele completava: "as Damas do Serralho poderiam julgar pela cor dos eunucos que há homens mais belos do que aquele a quem elas pertencem, e, por isso, não teriam tanto amor por ele" (CHARDIN, 1711, tomo 6, p. 231). Para o viajante, os eunucos ainda eram capazes de dar e receber prazer no contato com as mulheres. $\mathrm{O}$ segundo grupo era o de eunucos negros. Colocavam-se os velhos e os decrépitos para se aproximarem das mulheres e lhes passarem recados. Os outros eram empregados em trabalhos que exigiam o contato entre o palácio e a parte externa. E, por fim, o terceiro corpo de guardas era aquele das jovens: as favoritas do rei e as suas senhoras. Dentro deste grupo, havia sempre uma mulher mais velha do que as moças do serralho que tinha a função de "mãe" para governá-las (p. 232).

As mulheres eram abrigadas separadamente, ou no máximo dividiam o quarto com outra mulher. Nesse caso, explicava Chardin, ficavam no quarto "uma jovem e uma velha", não se podendo fazer visitas aos quartos, a menos que se tivesse permissão para tanto. Cada uma recebia uma pensão - paga em "prata e em tecidos" -, além de comida e certo número de empregados que compreendia de quatro a cinco servos e dois eunucos, com idade abaixo de dez anos e acima de cinquenta. O autor informava ainda que a pensão poderia variar de acordo com o grau de favorecimento recebido. No mais, elas eram tratadas da mesma maneira. 
O viajante afirmava que as mulheres eram "observadas muito de perto, com medo de que façam intrigas ou complôs contra as suas rivais, ou que se apaixonem umas pelas outras" (CHARDIN, 1711, tomo 6, p. 232). Em seguida, Chardin trataria de um tema já mencionado por Michel Baudier. O joalheiro assegurava que as mulheres Orientais sempre foram consideradas Tríbades, ou seja, homossexuais. O viajante declarava ser capaz de garantir que elas podiam saciar as paixões umas das outras. Então, impedia-se que elas se satisfizessem, porque tais relações reduziam os seus encantos, tornando-as "menos sensíveis ao amor dos homens" (p. 232).

A associação imediata do homoerotismo às mulheres islâmicas era recorrentemente relacionada ao convívio nos mesmos espaços físicos. O fato de ficarem juntas em um ambiente privado dentro do palácio, ou de se encontrarem nas casas de banho [hammām] são razões que aparecem com frequência em autores asiáticos e europeus. Sobre o primeiro grupo, encontramos já em Al-Makhzoumi, médico muçulmano do período clássico, a afirmação de que as mulheres reclusas ao harém mantinham relações sexuais umas com as outras (1994, p. 106). Séculos mais tarde, o escritor francês Pierre de Brantôme (c. 1540-1614), em sua obra Les dames galantes, escrevia que as mulheres, quando reunidas em um lugar fechado, tinham o seu corpo ardendo e buscavam remédio para resfriá-lo. Ele terminava afirmando que as turcas iam aos banhos "mais para esta obscenidade do que qualquer outra coisa, dedicando-se [a isso] intensamente" (BRANTÔME, 1666 apud JODELET, 2007, p. 117). 
Muitas das mulheres que provocavam situações de ódio ou de traições no harém já não esperavam mais sair dali. Por isso, buscavam formas de atrair a atenção do soberano. Para Chardin, as situações de ciúme e de traição geravam efeitos cruéis, porque o rei encontrava somente mulheres pérfidas e nenhum amor sincero. $\mathrm{O}$ resultado é que o soberano degradava a umas, transformava favoritas em escravas e provocava um cenário ainda mais devastador: além de castigos corporais feitos com chicotes, chegava a ordenar que se queimassem algumas mulheres e enterrassem outras vivas (CHARDIN, 1711, tomo 6, p. 233).

$\mathrm{O}$ viajante ouvira dizer que as mulheres do "harém ou serralho" se utilizavam de sortilégios para aborrecerem as suas rivais, ou para torná-las estéreis, ou ainda para se fazerem amadas, o que implicava aprisionar o "espírito" do senhor do lugar e ter filhos com ele. Este tipo de feitiço é que levaria o senhor do serralho a se apaixonar por uma "escrava negra, ou mal feita, em meio a muitas pessoas admiravelmente belas" (CHARDIN, 1711, tomo 6, p. 233-234). Esta afirmação pode nos dar pistas sobre o padrão de beleza feminino para um europeu do século XVII (DAVIS et al., 1993, p. 58).

Para Chardin, "o harém do rei da Pérsia é incomparável no que se refere à beleza das mulheres que ele guarda”, pois afluíam para esse local as moças mais belas do reino. Além disso, nesse lugar havia somente mulheres virgens. O autor informava a origem de tais moças: elas eram georgianas, circassianas, ibéricas e de "outras Províncias, onde parece que a beleza difunde os seus charmes com muito mais generosidade do que em qualquer outro lugar do mundo" (1711, tomo 6, p. 227). Informação similar 
pode ser encontrada em outro viajante francês, François Bernier, que, em sua viagem pelo Império Otomano, ressaltava a beleza das escravas da Circássia, local onde se achavam as "mais belas mulheres do mundo", de acordo "com todos os viajantes” (1671 apud STUURMAN, 2000, p. 6).

Para Chardin, contudo, a beleza não era o único elemento a retratar o harém, pois o "Serralho do Rei é comumente uma prisão perpétua, da qual se sai somente por um golpe do acaso" (1711, tomo 6, p. 227). O viajante havia mencionado, um parágrafo antes, que a entrada no harém poderia gerar bons frutos financeiros para a família da jovem escolhida. É certo que nesse processo os interesses da moça negociada acabavam sobrepujados pelas intenções lucrativas de sua própria família. Afinal, como ele notou, se uma moça "caísse nas graças do soberano", tornando-se confidente ou ama, a pensão dos pais desta mulher poderia aumentar. Se a jovem gerasse filhos do rei, a pensão poderia se estender a toda a família da moça (p. 226-227).

Chardin retratou a partir daí os problemas frequentes e cotidianos daquelas que viviam confinadas ao harém. Inicialmente, havia lugar para as "mais horríveis abominações do mundo", como os abortos forçados ou a recusa em amamentar bebês, levando-os à morte. As mulheres que tivessem o primeiro filho com o rei poderiam ter melhor posição e gozar a felicidade de ser mãe de um soberano. Mas as outras eram relegadas a um canto do serralho com os seus filhos, sentindo permanentemente a angústia de se verem privadas de suas vidas (CHARDIN, 1711, tomo 6, p. 227). Afora isso, muitas eram enviadas a ministros e a oficiais de Estado como forma de o soberano pleitear favores junto a eles. Chardin concluía disso que uma 
moça com tal destino era feliz, pois esta poderia se tornar “esposa legítima” (p. 228). Este desfecho, porém, era para poucas. Diante disso, o serralho retratado por Chardin seria mais sinônimo de tensão, de medo e de desesperança do que de tranquilidade e regozijo.

Ao lado da explicação de como as mulheres viviam dentro do serralho imperial, Chardin se dedicou, no capítulo XIII do Tomo 6, a descrever de que modo ocorriam os passeios de tais mulheres. As "Mulheres de qualidade" saíam do palácio apenas à noite, seguidas de uma escolta de cavaleiros que gritava "courouc", palavra que Chardin alegava ser turca, significando "defesa", "abstinência", para indicar que as pessoas da cidade não deveriam se aproximar. Os eunucos também caminhavam ao lado das mulheres para resguardá-las. As próprias ruas por onde passariam essas mulheres eram povoadas de tendas, como se fossem muralhas de proteção (CHARDIN, 1711, tomo 6, p. 238-239).

Assim como o advogado inglês Henry Blount e os franceses Henry de Beauvau, Louis Deshayes de Courmenin e Michel Baudier, o joalheiro também mencionou a presença de rapazes no serralho do soberano otomano. Ainda que a viagem de Chardin fosse pelo Império Persa, ele pôde presenciar uma guerra na Mingrélia que contou com a presença dos turcos. Ocorre que a Mingrélia - assim como outros reinos georgianos - sofriam constantes intervenções militares da Pérsia e do Império Otomano. No momento em que Chardin viajava pelo local, em 1671, ele presenciou mais uma investida otomana nessa região. A partir desta experiência, ele relatou que o Grão-Senhor otomano havia mandado ordens para destruir todas as 
fortalezas de Mingrélia. A presença dos turcos na região gerou, além disso, o aprisionamento de "uma multidão de jovens rapazes bem feitos" que foram levados ao serralho de Istambul (CHARDIN, 1686, tomo 1, p. 188).

A esse respeito há um dado importante. No "Índice Analítico" da primeira edição, ressaltava-se que tanto a prostituição de moças quanto a de rapazes era defendida (CHARDIN, 1711, tomo 10). Já na edição de 1811, encontramos que a "prostituição dos rapazes é defendida na Pérsia e permitida na Turquia" (tomo 10, p. 284). Na mesma edição, para a palavra "Turcos" havia a afirmação: "permitem o uso de rapazes" (p. 291). Nesse caso, a observação era idêntica àquela encontrada na primeira edição. Consultando-se o Tomo II, que é o volume ao qual o item remete, pode-se ler sobre o "pecado contra a natureza" (CHARDIN, 1711, tomo 10, p. 258) que os turcos cometiam, mas que os persas condenavam. Essa ideia era muito similar aos amores não naturais que lemos em Michel Baudier.

Dadas as descrições detalhadas encontradas ao longo de sua obra, a dúvida que se levanta é sobre a origem das informações veiculadas pelo viajante. Chardin respondia que a maior parte desses relatos era proveniente de um eunuco da tia do rei, o qual havia servido durante longo tempo no serralho de sua senhora. Ele havia feito o eunuco compreender que a sua "curiosidade não tinha outro princípio senão o desejo de informar o povo da Europa sobre as maneiras persas, que eram tão desconhecidas". Tal justificativa teria convencido o eunuco a lhe fornecer descrições sobre este "tema com muita facilidade e com muita confiança” (CHARDIN, 1711, tomo 6, p. 230). 
O tema do harém foi explorado também no tomo oitavo de sua obra. Chardin colocava ali uma afirmação que seria repetida no décimo volume das "Viagens", qual seja, a de que o harém "ou a parte sagrada [do palácio]" era o nome que se dava "aos apartamentos das mulheres" (1711, tomo 8, p. 191). Em seguida, o viajante afirmava que esse lugar era onde o senhor passava os dias com a sua mulher e com as crianças, por isso, era tomado como um lugar de prazer. Chardin, entretanto, opunha-se a essa ideia, justificando:

É por esta razão que os Turcos e os Tártaros chamam o apartamento das mulheres de Serralho, nome ao qual nós atribuímos uma ideia de Luxúria, mas que significa, entre os Orientais, Palácio ou Hotel [habitação ampla], como se dissesse que aquele lugar é propriamente o aposento e a casa de um Senhor (1711, tomo 8, p. 191).

No "Índice" geral de sua obra, abaixo do item "serralho" (tomo 10), Chardin colocava a seguinte frase: "ideia falsa que nós temos quanto ao significado desta palavra". A explicação sobre essa concepção errada era remetida justamente ao trecho citado acima. Se houve a necessidade de desfazer o equívoco acerca da luxúria no harém é porque a ideia se manifestava, em menor ou em maior grau, entre os europeus. Importante destacar também que o volume contendo tal índice foi publicado em 1711. Isso nos leva a pensar que desde pelo menos a segunda metade do século XVII começavam a se desenhar mudanças visíveis na produção textual - não apenas de viagem - sobre o Levante.

As mudanças ou as permanências nas imagens sobre o harém somente ficarão evidentes quando confrontarmos 
as representações elaboradas pelos viajantes Seiscentistas com a produção de viagem do século XVIII. Os relatos dos próximos autores, somados às referências apontadas neste capítulo, permitirão a construção de um quadro comparativo entre os textos. Tal espaço de análise deverá considerar os elementos comumente empregados na construção narrativa, assim como a circulação das ideias sobre o harém apresentadas nessas obras. Pretende-se que a "rede de relações" estabelecida entre a narrativa e o seu espaço de fomentação nos revele o processo de montagem das representações europeias sobre o harém, tema de análise do Capítulo 3. 